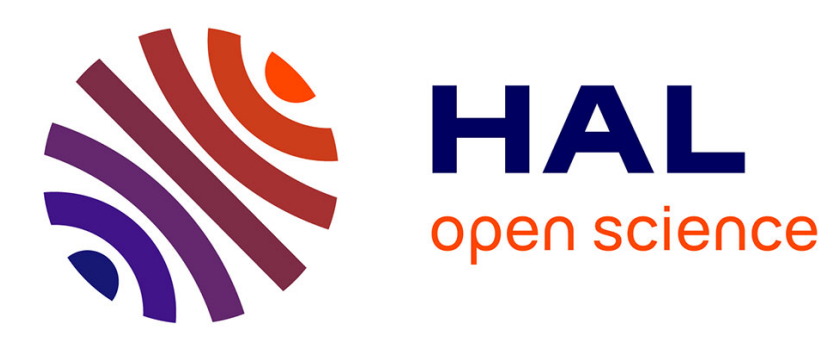

\title{
Plant-growth-promoting rhizobacteria to improve crop growth in saline soils: a review
}

Diby Paul, Harshad Lade

\section{To cite this version:}

Diby Paul, Harshad Lade. Plant-growth-promoting rhizobacteria to improve crop growth in saline soils: a review. Agronomy for Sustainable Development, 2014, 34 (4), pp.737-752. 10.1007/s13593014-0233-6 . hal-01234840

\section{HAL Id: hal-01234840 \\ https://hal.science/hal-01234840}

Submitted on 27 Nov 2015

HAL is a multi-disciplinary open access archive for the deposit and dissemination of scientific research documents, whether they are published or not. The documents may come from teaching and research institutions in France or abroad, or from public or private research centers.
L'archive ouverte pluridisciplinaire HAL, est destinée au dépôt et à la diffusion de documents scientifiques de niveau recherche, publiés ou non, émanant des établissements d'enseignement et de recherche français ou étrangers, des laboratoires publics ou privés. 


\title{
Plant-growth-promoting rhizobacteria to improve crop growth in saline soils: a review
}

\author{
Diby Paul • Harshad Lade
}

Accepted: 18 May 2014 / Published online: 13 June 2014

(C) INRA and Springer-Verlag France 2014

\begin{abstract}
Saline soils are a major issue for agriculture because salt turns agronomically useful lands into unproductive areas. The United Nations Environment Program estimates that approximately $20 \%$ of agricultural land and $50 \%$ of cropland in the world is salt-stressed. Soil salinisation is reducing the area that can be used for agriculture by $1-2 \%$ every year, hitting hardest in the arid and semi-arid regions. Salinity decreases the yield of many crops because salt inhibits plant photosynthesis, protein synthesis and lipid metabolism. Plant-growth-promoting rhizobacteria (PGPR), beneficial bacteria that live in the plant root zone named the rhizosphere, is one of the solutions to solve this issue. Indeed rhizobacteria counteract osmotic stress and help plant growth. This article reviews the benefits of plant-growth-promoting rhizobacteria for plants growing in saline soils. The major points are (1) plants treated with rhizobacteria have better root and shoot growth, nutrient uptake, hydration, chlorophyll content, and resistance to diseases; (2) stress tolerance can be explained by nutrient mobilisation and biocontrol of phytopathogens in the rhizosphere and by production of phytohormones and 1aminocyclopropane-1-carboxylate deaminase; (3) rhizobacteria favour the circulation of plant nutrients in the rhizosphere; (4) rhizobacteria favour osmolyte accumulation in plants; (5) plants inoculated with rhizobacteria have higher $\mathrm{K}^{+}$ion concentration and, in turn, a higher $\mathrm{K}^{+} / \mathrm{Na}^{+}$ratio that favour salinity tolerance; and (6) rhizobacteria induce plant synthesis of antioxidative enzymes that degrade reactive oxygen species generated upon salt shock.
\end{abstract}

D. Paul $(\bowtie) \cdot$ H. Lade

Environmental Microbiology, Department of Environmental Engineering, Konkuk University, 120 Neungdong-ro, \#Gwanjin-gu Seoul 143-701, Republic of Korea

e-mail: dibypaul@live.com
Keywords Soil salinity $\cdot$ Plant-growth-promoting rhizobacteria $\cdot$ Mitigation $\cdot$ Osmotolerance $\cdot$ Nutrient uptake . Plant growth

Contents

1. Introduction $\ldots \ldots \ldots \ldots \ldots \ldots \ldots \ldots \ldots \ldots \ldots \ldots \ldots \ldots \ldots \ldots$

2. Soil salinity: a global issue $\ldots \ldots \ldots \ldots \ldots \ldots 2$

2.1. The magnitude of the problem ........... 2

2.2. Soil Salinization: The process ........... 3

3. Impact of soil-salinity on plant growth and development . 4

4. Impact of soil salinity on rhizospheric microbial diversity . 4

5. Mechanisms of osmotolerance in rhizobacteria .... 6

6. Mitigation of salt stress in crops by PGPRs. . . . . 6

6.1. PGPRs as effective candidates in salt stress amelioration in plants .................... 6

6.2. PGPR mediated plant root proliferation and plant vigor $\ldots \ldots \ldots \ldots \ldots \ldots \ldots \ldots$

6.3. Bacterial production of phytohormones $\ldots \ldots .8$

6.4. PGPR act as sink for ACC ............ 9

6.5. PGPR mediated ion homeostasis $\ldots \ldots \ldots \ldots 9$

6.6. Accumulation of osmolytes $\ldots \ldots \ldots \ldots \ldots 10$

6.7. Antioxidative Enzymes ............. 10

6.8. Bacterial Extracellular Polymeric Substance in plant stress alleviation $\ldots \ldots \ldots \ldots \ldots \ldots \ldots . \ldots \ldots$

6.9. Enhancement of plant nutrient uptake . . . . . 10

6.10. PGPR mediated disease suppression . . . . . . 11

7. Conclusion $\ldots \ldots \ldots \ldots \ldots \ldots \ldots \ldots \ldots \ldots \ldots \ldots$

8. References ..................... 12

\section{Introduction}

Soil salinity in agriculture soils refers to the presence of high concentration of soluble salts in the soil moisture of the root zone. These concentrations of soluble salts through their high 
osmotic pressures affect plant growth by restricting the uptake of water and balanced absorption of essential nutritional ions by the roots (Tester and Davenport 2003). Salinity is one of the most serious factors limiting the productivity of agricultural crops, with adverse effects on germination, plant vigour and crop yield (Munns and Tester 2008). In a majority of cultivated plants, yields start declining even at relatively low salinity in soil (electrical conductivity, ECse $>1 \mathrm{dS} / \mathrm{m}$ ) (Chinnusamy et al. 2005). Some of the most produced and widely used crops such as rice is relatively susceptible to excessive concentration of salts (Howell 2001), and currently, $30 \%$ of worldwide paddy fields are affected by excess salinity (Rowell 1994).

Developing salt-tolerant crops has been a much desired scientific goal but with little success (Munns and Tester 2008). Successful remediation of salt degraded areas for crop production, based on sustainable management practices evolving efficient, low cost, easily adaptable methods, is the challenge. In addition, sustainable management practices in agriculture is essentially important as it offers the potential to meet our future agricultural needs, something that conventional agriculture will not be able to do. Recently, there has been a great interest in eco-friendly and sustainable agriculture with emphasis on the use of beneficial microorganisms. Indeed, several recent studies have demonstrated that local adaptation of plants to their environment is driven by genetic differentiation in closely associated microbes (Rodriguez and Redman 2008). Rhizosphere microorganisms have been shown to enhance the growth of many different crops grown in a wide range of root-zone salinities, and this approach is believed succeed where it has proved difficult to develop salt-tolerant germplasm.

Microorganisms that live in close association with the plant roots play a significant role in stress alleviation in crops grown in saline soils due to their unique properties of tolerance to extremities, their interaction with crop plants and potential deployment methods. About $2-5 \%$ of rhizobacteria, when reintroduced by plant inoculation in a soil containing competitive microflora, exert a beneficial effect on plant growth and are termed as plant-growth-promoting rhizobacteria (PGPR). PGPR were first defined by Kloepper and Schroth (1978) to describe soil bacteria that colonise the roots of plants following inoculation onto seed, and they enhance plant growth. They are involved in various biotic activities of the soil ecosystem to make it dynamic for nutrient turn over and sustainable for crop production (Chandler et al. 1986; Diby et al. 2005a, b). They stimulate plant growth through mobilising nutrients in soils, producing numerous plant growth regulators, protecting plants from phytopathogens by controlling or inhibiting them, improving soil structure and bioremediating the polluted soils by sequestering toxic heavy metal species and degrading xenobiotic compounds (Braud et al. 2009; Hayat et al. 2010).
Use of these microorganisms in stressed soils can alleviate stresses in crop plants, thus opening a potential and promising strategy in sustainable agriculture. Several studies are now proving the hypothesis that PGPRs enable agricultural plants to maintain productivity under stressed conditions by various means, and the results are promising. These microbes also provide excellent models for understanding the stress tolerance, adaptation and response mechanisms that can be subsequently engineered into crop plants to cope with climate change induced stresses (Grover et al. 2011). Improvement in agricultural sustainability in saline soils inevitably requires management practices that enhance soil biological activity and thereby build-up long-term soil productivity and crop health.

\section{Soil salinity: a global issue}

\subsection{The magnitude of the problem}

Salinity is a significant problem affecting agriculture worldwide and is predicted to become a larger problem in the coming decades. Soil salinisation is reducing the area that can be used for agriculture by 1-2\% every year, hitting hardest in the arid and semi-arid regions (The Food and Agriculture Organization of the United Nations (FAO) 2002). As salt levels that are harmful to plant growth affect large terrestrial areas of the world, agricultural productivity is severely affected by soil salinity. It has been estimated that on a world-wide scale, the production by approximately 400 million hectares of arable land is being severely restricted by salinity (Bot et al. 2000). According to the Food and Agriculture Organization of the United Nations, Land and Plant Nutrition Management Service, over $6 \%$ of the world's land is salt-affected (Table 1). The Food and Agriculture Organization of the United Nations (FAO, 1988) estimates that, of the 250 million hectares of irrigated land in the world, approximately $50 \%$ already show salinisation and soil saturation problems, and 10 million hectares are abandoned annually due to these problems. The United Nations Environment Program estimates that approximately $20 \%$ of agricultural land and $50 \%$ of cropland in the world is salt-stressed (Flowers and Yeo 1995).

Salt stress as one of the most widespread abiotic constraints in food production may also result in the negative ecological, social and/or economic outcomes. For instance, recent deposition of toxic salt sediments and sea intrusion in tsunamiaffected areas of Maldives damaged $>70 \%$ of agriculture land, destroyed $>370,000$ fruit trees and affected around 15,000 farmers (The Food and Agriculture Organization of the United Nations (FAO) 2005). Postel (1998) estimates that soil salinisation costs the world's farmers $\$ 11$ billion a year in reduced income and warns that the figure is growing. 
Table 1 Salt-affected soils occur in all continents and under almost all climatic conditions

\begin{tabular}{llllll}
\hline Regions & Total area & Saline soils & \multicolumn{2}{l}{ Sodic soils } \\
\hline & Mha & Mha & $\%$ & Mha & $\%$ \\
Africa & 1,899 & 39 & 2.0 & 34 & 1.8 \\
Asia, the Pacific and Australia & 3,107 & 195 & 6.3 & 249 & 8.0 \\
Europe & 2,011 & 7 & 0.3 & 73 & 3.6 \\
Latin America & 2,039 & 61 & 3.0 & 51 & 2.5 \\
Near East & 1,802 & 92 & 5.1 & 14 & 0.8 \\
North America & 1,924 & 5 & 0.2 & 15 & 0.8 \\
Total & 12,781 & 397 & 3.1 & 434 & 3.4 \\
\end{tabular}

Their distribution, however, is relatively more extensive in the arid and semi-arid regions compared to the humid regions. The table shows the regional distribution of salt-affected soils, in million hectares. Source: The Food and Agriculture Organization of the United Nations, Land and Plant Nutrition Management Service

Coastal wet lands and coastal agricultural zones too are seriously affected by the salinity issue. Coastal wetlands comprise various habitat types, including salt marshes, mangroves, seagrasses, salt swamps, and sand dunes, because of their transitional situation between sea and terrestrial ecosystems, affected by salinity (Armstrong et al. 1985; Bharathkumar et al. 2008). Out of about 8.1 million hectares of salinised land in India, 3.1 million are reported to be in coastal regions (Tripathi et al. 2000).

\subsection{Soil salinisation: the process}

Salinisation consists of an accumulation of water soluble salts in the soil that include the ions potassium $\left(\mathrm{K}^{+}\right)$, magnesium $\left(\mathrm{Mg}^{2+}\right)$, calcium $\left(\mathrm{Ca}^{2+}\right)$, chloride $\left(\mathrm{Cl}^{-}\right)$, sulfate $\left(\mathrm{SO}_{4}{ }^{2-}\right)$, carbonate $\left(\mathrm{CO}_{3}{ }^{2-}\right)$, bicarbonate $\left(\mathrm{HCO}^{3-}\right)$ and sodium $\left(\mathrm{Na}^{+}\right)$. Depending on soils, the extracted solutions differ in the content of dissolved salts; if total salt concentration, i.e. electrical conductivity (ECse), exceeds $20 \mathrm{mM}(\sim 2 \mathrm{dS} / \mathrm{m})$, they can be categorised as salt-affected (Abrol et al. 1988). The salinisation processes may be primary (natural) and secondary (anthropogenic) (Ghassemi et al. 1995). The major causes of naturally induced salinity are salt water intrusion and windborn salt deposition in land. Mediterranean regions are currently experiencing increasing salt stress problems resulting from seawater intrusion into aquifers and irrigation with brackish water (Rana and Katerji 2000). Another major cause for soil salinity is the deposition of oceanic salt carried in wind and rain. Salts originate also from mineral weathering. The anthropogenic factors include crop irrigation with salt waters wherein soil salinisation is dramatically exacerbated and accelerated. The other factors may be inorganic fertilisers, soil amendments (e.g. gypsum, composts and manures) (KotubyAmacher et al. 2000).
Although Earth abounds in water, an almost negligible portion $\left(\sim 2.5 \%\right.$ or 35 million $\left.\mathrm{km}^{3}\right)$ is fresh or with low salt concentration $(<1 \mathrm{dS} / \mathrm{m}$ ) (Ondrasek et al. 2010; Shiklomanov and Rodda 2003), i.e. water that may be conditionally used for irrigation in crop production, whereas the rest is salty and therefore unsuitable for irrigation. However, it has been estimated that irrigated agriculture consumes $\sim 70 \%$ (and $>90 \%$ in many developing countries) of total water withdrawal to produce $\sim 36 \%$ of global food (Howell 2001). As a consequence, there is a continuous degradation of land resources (e.g. salt-affected soils), representing a large burden to natural ecosystems. When salt accumulates in the soil, excessive sodium $\left(\mathrm{Na}^{+}\right)$from salt destroys soil structure, deteriorates soil hydraulic properties, raises soil $\mathrm{pH}$ and reduces water infiltration and soil aeration, leading to soil compaction, increasing erosion and water run-off. Furthermore, sodium is the most pronounced destructor of secondary clay minerals by dispersion. Dispersion occurs because of $\mathrm{Na}^{+}$replacement of calcium $\left(\mathrm{Ca}^{2+}\right)$ and other coagulators like $\mathrm{Mg}^{2+}$ adsorbed on the surface and/or inter-layers of soil aggregates (Ondrasek et al. 2010). Dispersed clay particles undergo leaching through the soil and may accumulate and block pores, especially in fine-textured soil horizons (Burrow et al. 2002). The soil becomes unsuitable for proper root growth and plant development.

\section{Impact of soil salinity on plant growth and development}

Salinity affects plant growth and yield in many of crops in varying degrees (Table 2). Crops such as cereals (rice and maize), forages (clover) or horticultural crops (potatoes and tomatoes) are relatively susceptible to excessive concentration of salts, either dissolved in irrigation water or present in soil (rhizosphere) solution. Soil salinity has been reported to reduce yields, nodulation and the total nitrogen content in legume plants (Singleton and Bohlool 1984). El-Fouly et al. (2001) found that the dry weight of different plant organs of tomato was reduced in response to the increase of $\mathrm{NaCl}$ level in the root growth medium.

During the onset and development of salt stress within a plant, all the major processes such as photosynthesis, protein synthesis and energy and lipid metabolism are affected (Parida and Das 2005). Photosynthetic capacity is reduced, due to the osmotic stress and partial closure of stomata (Meloni et al. 2003). Plants can also suffer from membrane destabilisation and a general nutrient imbalance (Hasegawa et al. 2000). Further plant responses to osmotic stress are decrease in cell growth and development, reduced leaf area and chlorophyll content, accelerated defoliation and senescence (Shannon and Grieve 1999). Figure 1 shows saline patch of soil in a wheat field (Uttar Pradesh, India) that clearly hinders plant growth.

An increase in the uptake of $\mathrm{Na}^{+}$or decrease in the uptake of $\mathrm{Ca}^{2+}$ and $\mathrm{K}^{+}$in leaves lead to nutritional imbalances. 
Table 2 Excess soil salinity causes poor and spotty stands of crops, uneven and stunted growth and poor yields, the extent depending on the degree of salinity

\begin{tabular}{lll}
\hline Soil salinity class & $\begin{array}{l}\text { Conductivity of the } \\
\text { saturation extract }(\mathrm{dS} / \mathrm{m})\end{array}$ & Effect on crop plants \\
\hline Non-saline & $0-2$ & Salinity effects negligible \\
Slightly saline & -4 & Yields of sensitive crops may be restricted \\
Moderately saline & $4-8$ & Yields of many crops are restricted \\
Strongly saline & $8-16$ & Only tolerant crops yield satisfactorily \\
Very strongly saline & $>16$ & Only a few very tolerant crops yield satisfactorily \\
\hline
\end{tabular}

As the salinity increases growth decreases until plants become chlorotic and die. Plants differ widely in their ability to tolerate salts in the soil. Salt tolerance ratings of plants are based on yield reduction on salt-affected soils when compared with yields on similar non-saline soils. Soil salinity classes and crop growth are listed in the table. Source: The Food and Agriculture Organization of the United Nations, Soils Bulletin

Accumulation of excess $\mathrm{Na}^{+}$may cause metabolic disturbances in processes where low $\mathrm{Na}^{+}$and high $\mathrm{K}^{+}$or $\mathrm{Ca}^{2+}$ are required for optimum function. Excess sodium and more importantly chloride has the potential to affect plant enzymes and cause cell swelling, resulting in reduced energy production and other physiological changes (Larcher 1980). Uptake and accumulation of $\mathrm{Cl}^{-}$disrupt photosynthetic function through the inhibition of nitrate reductase activity ( $\mathrm{Xu}$ et al. 2000). Under excessive $\mathrm{Na}^{+}$and $\mathrm{Cl}^{-}$rhizosphere concentration, there are competitive interactions with other nutrient ions $\left(\mathrm{K}^{+}, \mathrm{NO}^{3-}\right.$ and $\left.\mathrm{H}_{2} \mathrm{PO}_{4}{ }^{-}\right)$for binding sites and transport proteins in root cells, and thereafter for translocation, deposition and partitioning within the plant (Tester and Davenport 2003). Once the capacity of cells to store salts is exhausted, salts build up in the intercellular space leading to cell dehydration and death (White and Broadley 2001).

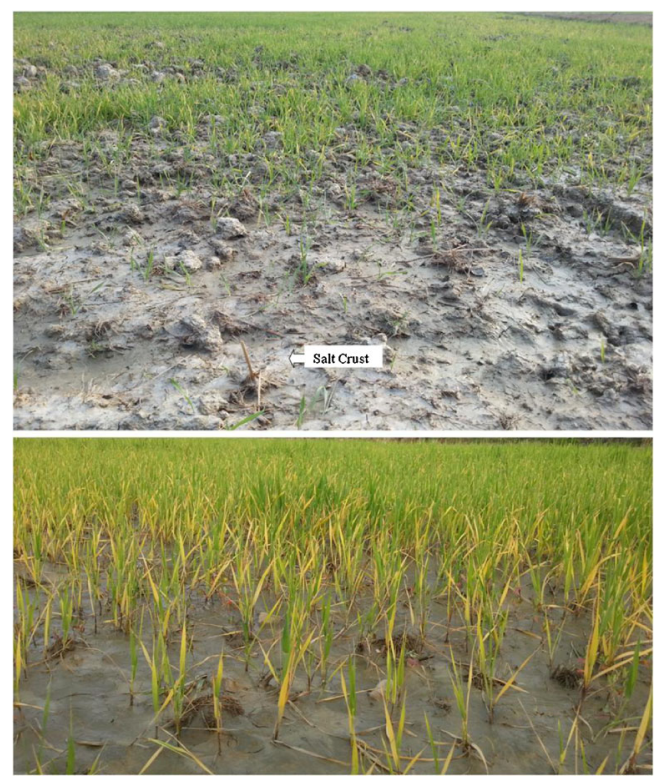

Fig. 1 A saline patch of soil in a wheat field clearly hinders plant growth. The photos were taken in Varanasi, Uttar Pradesh, India. Salt causes yellowing and death of wheat leaves. Salt-affected soil often exhibits a white or grey salt crust on the ground and the salt interferes with the growth of most plants
Under saline conditions, osmotic pressure in the rhizosphere solution exceeds that in root cells, influencing water and nutrient uptake. Almost all micro- and macronutrient contents decrease in the roots and shoots with increasing $\mathrm{NaCl}$ concentration in the growth medium. Salama et al. 1996 reported limited uptake of nutrients in different organs of wheat plants when there was high salt concentration in the root growth medium. The plants with perturbed nutrients relations are more susceptible to invasion of different pathogenic microorganisms and physiological dysfunctions, whereas their edible parts have markedly less economic and nutritional value due to reduced fruit size and shelf life, non-uniform fruit shape, decreased vitamin content, etc. (Romic et al. 2008).

The primary salinity effects give rise to numerous secondary ones such as oxidative stress, characterised by accumulation of reactive oxygen species potentially harmful to biomembranes, proteins, nucleic acids and enzymes (Porcel et al. 2012). To protect against oxidative stress, plant cells produce both antioxidant enzymes and non-enzymatic antioxidants (Hasegawa et al. 2000), and the modulation of antioxidant enzyme activity and concentrations are frequently used as indicators of oxidative stress in plants (Mayak et al. 2004).

\section{Impact of soil salinity on rhizospheric microbial diversity}

The microbial biomass is an important labile fraction of the soil organic matter, functioning both as an agent of transformation and recycling of the organic matter and soil nutrients, as also of a source of nutrients for the plants. It is well known that the environments of plant rhizospheres are more favourable microhabitats for microorganisms compared to surrounding bulk soils (Bais et al. 2006), and these microbes directly or indirectly influence plant growth and development. In addition, as the availability of nutrients for plants is regulated by the rhizospheric microbial activity, any factor affecting this community and its functions influences the availability of nutrients and growth of the plants. Enhanced microbial 
biomass and activities by rhizosphere effects are important to ecosystem functioning and pollutant degradation in natural ecosystems, plant health as well as in contaminated environments (Nie et al. 2009; Wenzel 2009).

Since the soil organic matter, and consequently the biomass and microbial activity, are generally more relevant in the first few centimetres at the surface of the soil, salinisation close to the surface can significantly affect a series of microbiologically mediated processes. The detrimental influence of salinity on the microbial soil communities and their activities reported in naturally saline soils (Rietz and Haynes 2003; Sardinha et al. 2003). Salinity has a negative impact on microbial abundance, diversity, composition and functions (Borneman et al. 1996). Omar et al. (1994) showed that, with an increase in the salinity level to above $5 \%$, the total count of bacteria and actinobacteria was drastically reduced. Salinity stress was shown to reduce the attachment of Azospirillum brasilense to maize and wheat roots (Jofre et al. 1998). In addition, increase in salinity inhibited nitrogen fixation at the level of nifH expression and nitrogenase activity in Azospirillum sp. (Tripathi et al. 2002). Increased salinity in the rhizosphere affects root exudation and decomposition of organic matter by microorganisms (Ondrasek et al. 2010). Similar observation were reported by Li et al. (2006), who noticed significant negative correlations between soil electrical conductivity and total $\mathrm{CO}_{2}$ emission or microbial biomass $\mathrm{C}$, suggesting that salinity had an adverse effect on microbial biomass and activity. Therefore, naturally occurring soil organic matter decomposers may be sensitive to salt-induced stress. This effect is always more pronounced in the rhizosphere pursuant to increased water uptake by the plants due to transpiration.

Nelson and Mele (2007) reported that sodium chloride is more likely to affect rhizosphere microbial community structure indirectly through root exudates quantity and/or quality than directly through microbial toxicity and that plant health is a major determinant in rhizosphere microbial community structure. For microbes, life in high salt concentrations is bioenergetically taxing because they must maintain an osmotic balance between their cytoplasm and the surrounding medium while excluding sodium ions from the cell interior, and as a result, sufficient energy is required for osmoadaptation (Jiang et al. 2007). Depletion of potassium ions by plants reduces the ability of rhizobacteria to use potassium ions as a primary osmoregulator (Jofre et al. 1998). Plant use of osmolytes under salt stress deprives rhizobacteria of osmolytes, which finally limits the bacterial growth. Alteration of proteins, exopolysaccharide and lipopolysaccharide composition of the bacterial cell surface, impairment of molecular signal exchange between bacteria and their plant host due to the alteration of membrane glucan contents, and inhibition of bacterial mobility and chemotaxis towards plant roots significantly affect microbial diversity in the rhizosphere, under saline conditions. Ibekwe et al. (2010) suggested that changes in microbial diversity may be the first indicator of stress in salinity-affected soils. Therefore, if stress can be detected early enough in salinity affected soils, then some remedial action may be possible to improve soil quality and crop performance.

\section{Mechanisms of osmotolerance in rhizobacteria}

Exposure of microorganisms to high-osmolality environments triggers rapid fluxes of cell water along the osmotic gradient out of the cell, thus causing a reduction in turgor and dehydration of the cytoplasm. Microbes have developed various adaptations to counteract the outflow of water. The cytoplasm is exposed to high ionic strength to achieve osmotic equilibrium by maintaining a cytoplasmic salt concentration similar to that of the surrounding media. The first response to osmotic up shifts and the resulting efflux of cellular water is uptake of $\mathrm{K}^{+}$and also cells start to accumulate compatible solutes (Whatmore et al. 1990). The organic osmolytes include sugars and derivatives, amino acids and their derivatives, polyols and derivatives, betaines and ectoines (Lamosa et al. 1998). Compatible solutes could be synthesised de novo or, if present in the medium, can be taken up by the organisms. Paul and Nair (2008) reported that Pseudomonas fluorescens MSP-393, a PGPR strain, as a means of salt tolerance, de novo-synthesised, the osmolytes, alanine, glycine, glutamic acid, serine, thronine and aspartic acid in their cytosol. In addition to their wellstudied function as osmoprotectants, compatible solutes also have protein-stabilising properties that support the correct folding of polypeptides under denaturing conditions both in vitro and in vivo (Street et al. 2006).

Yet, another mechanism is by altering the cell envelope composition resulting in changes in proteins, periplasmic glucans and capsular, exo and lipopolysaccharides. Pseudomonas survive under stress conditions due to the production of exopolysaccharides, which protects them from hydric stress and fluctuations in water potential by enhancing water retention and regulating the diffusion of carbon sources in microbial environment (Sandhya et al. 2009). Klein et al. (1999) reported changes in the fatty acid composition of the bacterial membrane under osmotic stress, by varying the length of acyl chains, number of double bonds or branching of acyl chains by methyl groups. Salt stress induced higher levels of cyclopropane fatty acid (DC19:0) and lower levels of oleic acid (C18:1) in the lipid membrane of Lactococcus lactis (Guillot et al. 2000). A cross-linking of the peptidoglycan has also been shown to respond to variations in the salinity stress; $\mathrm{NaCl}$ stressed cells had shorter peptidoglycan inter-peptide bridges than the unstressed cells (Piuri et al. 2005). Francius et al. (2011) showed that the presence of loose, flexible surface appendage around the bacteria under low electrolyte concentration condition acts as a protective barrier, thereby 
attenuating the impact of changes in extracellular ionic strength and lowering the osmotic pressure constraint.

Bacteria initiate a program of gene expression in response to osmotic stress by high $\mathrm{NaCl}$ concentrations, which are manifested as a set of proteins produced in increased amounts in response to the stress (Volker et al. 1994). Diby et al. (2005a) demonstrated differentially expressed salt responsive genes in the salt-tolerant PGPR, Pseudomonas pseudoalcaligenes. Peptide mass fingerprinting analysis of $P$. fluorescens under salt shock conditions revealed several over-expressed/repressed stress related proteins (Paul et al. 2006). Majority of proteins identified were homologous to stress proteins in prokaryotes. These stress alleviation proteins is believed to play a major role in helping the bacteria to maintain its metabolism unaltered considerably, thus delivering the plantgrowth-promoting and biocontrol properties in saline soils (Paul et al. 2006). A transcriptional profiling of a saltstressed soil bacterium Bacillus subtilis in the presence of $1.2 \mathrm{M} \mathrm{NaCl}$ has been shown to trigger the induction of 123 genes and led to the repression of 101 genes (Steil et al. 2003). Use of macro-array technique in Escherichia coli revealed that $\mathrm{NaCl}$ stress altered the expression of 152 genes, out which 45 were up regulated, whereas the rest 107 were down-regulated (Weber and Jung 2002). Several of the up-regulated genes have been shown to be involved in the cellular processes of adaptation and protection and in the biosynthesis, metabolism and transport of amino acids. The transcriptome analysis in Shewanella oneidensis MR-1 revealed that high salinity caused up-regulation of genes involved in $\mathrm{Na}^{+}$eZux, $\mathrm{K}^{+}$ accumulation, glutamate biosynthesis and in aerobic as well as anaerobic respiration (Liu et al. 2005). Among genes potentially mediating $\mathrm{K}^{+}$transport across bacterial membranes, the most dramatic changes in response to $\mathrm{NaCl}$ stress were observed in the level of expression of the $\mathrm{K}^{+}$uptake protein kup/trkD (Shabala 2009). Very recently, it has been reported that the non-coding RNA named Yfr1 might be involved in salt sensing (Georg et al. 2009). The mechanisms of salt-tress adaptions in rhizobacteria have been recently reviewed by Paul (2013).

\section{Mitigation of salt stress in crops by PGPRs}

6.1 PGPRs as effective candidates in salt stress amelioration in plants

Salinity adversely affects the growth and yield of several crop plants, and soil aggregate stability is one of the most important properties controlling the growth of plants in semi-arid environments. Therefore, the improvement of soil structural stability is of great importance. The contribution of microbial populations, either as free-living organisms or associated with plant roots, and their activities to soil aggregate stability are proved to be highly beneficial (Jastrow and Miller 1991) in terms of rendering saline soils suitable for agriculture. Extensive research has been carried out on occurrence and functional diversity of agriculturally important microbes in stressed environments and their role in soil remediation, as reviewed by several authors (Graham 1992; Zahran 1999; Paul 2013). The occurrence of several of beneficial rhizobacteria like Rhizobium, Bradyrhizobium, Azotobacter, Azospirillum, Pseudomonas, Bacillus, etc. have been reported from stressed environments like desert ecosystems, acid soils, saline and alkaline areas and highly eroded hill slopes (Selvakumar et al. 2009; Upadhyay et al. 2009), and these are assumed to be involved in natural reclamation process of the soil.

Apart from developing mechanisms for own stress tolerance, PGPRs can also impart some degree of tolerance to plants, towards abiotic stresses like salinity. Interaction of PGPR with several crops in saline conditions reduced the extent of poor growth and thus helps plants survive and improve performance in adverse conditions (Dimkpa et al. 2009). Many studies have been published on beneficial effects of bacterial inoculation on plant physiology and growth under salt stress conditions and examples are summarised in Table Error! Reference source not found.. Some PGPR may exert a direct stimulation on plant growth and development by providing plants with fixed nitrogen, phytohormones, iron that has been sequestered by bacterial siderophores, and soluble phosphate (Hayat et al. 2010; Rodriguez and Fraga 1999). Others do this indirectly by protecting the plant against soil-borne diseases, most of which are caused by pathogenic fungi (Lugtenberg and Kamilova 2009). Soil-borne pseudomonads have received particular attention because of their catabolic versatility, excellent root-colonising ability and capacity to produce a wide range of enzymes and metabolites that help the plant withstand varied biotic and abiotic stress conditions (Vessey 2003). Various attributes of PGPRs in amelioration of salt stress in crops are summarised in Fig. 2.

\subsection{PGPR-mediated plant root proliferation and plant vigour}

PGPRs colonise the rhizosphere of plants and promote growth of the plants through various means. Paul and Sarma (2006) demonstrated using GS $\operatorname{Root}^{\circledR}$ software (PP systems, Winterstreet, USA) that the PGPR strain, P. fluorescens IISR-6, significantly enhanced the root biomass of black pepper vines. Rhizobacteria-mediated root proliferation has been well proved and it also works in stressed soils (Diby et al. 2005a). Hence, a fruitful strategy to alleviate negative effects of salt stress in plants might be the co-inoculation of seeds with different PGPR species. Inoculation of various plant species with PGPRs has also reported to lead to enhanced 
Table 3 Rhizobacteria impart some degree of tolerance to plants, towards salinity stress

\begin{tabular}{|c|c|c|}
\hline Rhizobacteria & Plant & Reference \\
\hline Bacillus safensis, Ochrobactrum pseudogregnonense & Wheat (Triticum aestivum) & Chakraborty et al. (2013) \\
\hline $\begin{array}{l}\text { Pseudomonas putida, Enterobacter cloacae, Serratia ficaria and } \\
\text { P. fluorescens }\end{array}$ & Wheat (T. aestivum) & Nadeem et al. (2013) \\
\hline Alcaligenes faecalis, Bacillus pumilus, Ochrobactrum sp. & Rice (Oryza sativa) & Bal et al. (2013) \\
\hline P. pseudoalcaligenes, B. pumilus & Rice $(O$ sativa $)$ & Jha et al. (2013) \\
\hline B. subtilis, Arthrobacter sp. & Wheat (T. aestivum) & Upadhyay et al. (2012) \\
\hline Azospirillum sp. & Wheat (T. aestivum) & Zarea et al. (2012) \\
\hline Streptomyces sp. & Wheat (T. aestivum) & Sadeghi et al. (2012) \\
\hline Pseudomonas sp., Bacillus sp., Variovorax sp. & Avocado (Persea gratissima) & Nadeem et al. (2012) \\
\hline Azotobacter chroococcum & Maize (Z. mays) & Rojas-Tapias et al. (2012) \\
\hline P. pseudoalcaligenes, $P$. putida & Chickpea (Cicer arietinum) & Patel et al. (2012) \\
\hline $\begin{array}{l}\text { Brachybacterium saurashtrense, Brevibacterium casei, } \\
\text { Haererohalobacter } \mathrm{sp} .\end{array}$ & Pea nut (Arachis hypogaea) & Shukla et al. (2012) \\
\hline P. extremorientalis, $P$. chlororaphis & Common bean (Phaseolus vulgaris) & Egamberdieva (2011) \\
\hline $\begin{array}{l}\text { Bacillus, Burkholderia, Enterobacter, Microbacterium, } \\
\quad \text { Paenibacillus }\end{array}$ & Wheat (T. aestivum) & Upadhyay et al. (2011) \\
\hline P. fluorescens, P. aeruginosa, P. stutzeri & Tomato (Lycopersicon esculentum) & Tank and Saraf (2010) \\
\hline Pseudomonas sp. & Eggplant (Solanum melongena) & Fu et al. (2010) \\
\hline Azospirillum sp. & Durum wheat (Triticum durum) & Nabti et al. (2010) \\
\hline P. putida & Cotton (Gossypium hirsutum) & Yao et al. (2010) \\
\hline B. megaterium & Maize (Zea maize L.) & Marulanda et al. (2010) \\
\hline $\begin{array}{l}\text { Agrobacterium rubi, Burkholderia gladii, P. putida, B. subtilis, } \\
\text { B. megaterium }\end{array}$ & Radish (Raphanus sativus L.) & Kaymak et al. (2009) \\
\hline A. brasilense & Barley (Hordeum vulgare) & Omar et al. (1994) \\
\hline P. mendocina & Lettuce (L. sativa L. cv. Tafalla) & Kohler et al. $(2009,2010)$ \\
\hline B. subtilis & Arabidopsis thaliana & Zhang et al. (2008) \\
\hline A. brasilense & Pea (Phaseolus vulgaris) & Dardanelli et al. (2008) \\
\hline Bacillus sp., Ochrobactrum sp. & Maize (Z. mays) & Principe et al. (2007) \\
\hline P. syringae, $P$. fluorescens, E. aerogenes & Maize (Z. mays) & Nadeem et al. (2007) \\
\hline P. fluorescens & Groundnut (Arachis hypogaea) & $\begin{array}{l}\text { Saravanakumar and Samiyappan } \\
\text { (2007) }\end{array}$ \\
\hline Azospirillum & Lettuce (L. sativa) & Barassi et al. (2006) \\
\hline P. fluorescence & Black pepper (Piper nigrum) & Paul and Sarma (2006) \\
\hline P. pseudoalcaligenes & Rice $(O$. sativa $)$ & Diby et al. (2005a) \\
\hline Achromobacter piechaudii & Tomato (L. esculentum) & Mayak et al. (2004) \\
\hline Aeromonas hydrophila, B. insolitus Bacillus sp. & Wheat (T. aestivum) & Ashraf et al. (2004) \\
\hline Azospirillum & Maize (Z. mays) & Hamdia et al. (2004) \\
\hline A. brasilense & $\begin{array}{l}\text { Chickpeas (C. arietinum), faba beans (Vicia } \\
\text { faba L.) }\end{array}$ & Hamaoui et al. (2001) \\
\hline A. lipoferum, A. brasilense, Azoarcus, Pseudomonas sp. & Kallar grass Leptochloa fusca) & Malik et al. (1997) \\
\hline
\end{tabular}

Interaction of beneficial rhizobacteria with several crops in saline conditions reduced the extent of poor growth and thus helped plants survive and improve performance in adverse conditions. Examples of rhizobacteria mediated plant tolerance to salinity stress are listed in the table

formation of lateral roots and root hairs that can result in enhanced tolerance to abiotic stress. Paul and Nair (2008) reported the root colonisation potential of the salt tolerant Pseudomonas strain was not hampered with higher salinity in soil. Promotion of root growth results in a larger root surface and can, therefore, have positive effects on water acquisition and nutrient uptake (Diby et al. 2005b; Paul and
Sarma, 2006) that is expected to alleviate the stress effects in the plant. In addition, Kohler et al. (2009) observed in lettuce that the plants inoculated with PGPRs were more hydrated than the control plants under saline conditions. Greater hydration induced by the PGPR strain might be attributable to increased water use efficiency (Saravanakumar and Samiyappan 2007). 


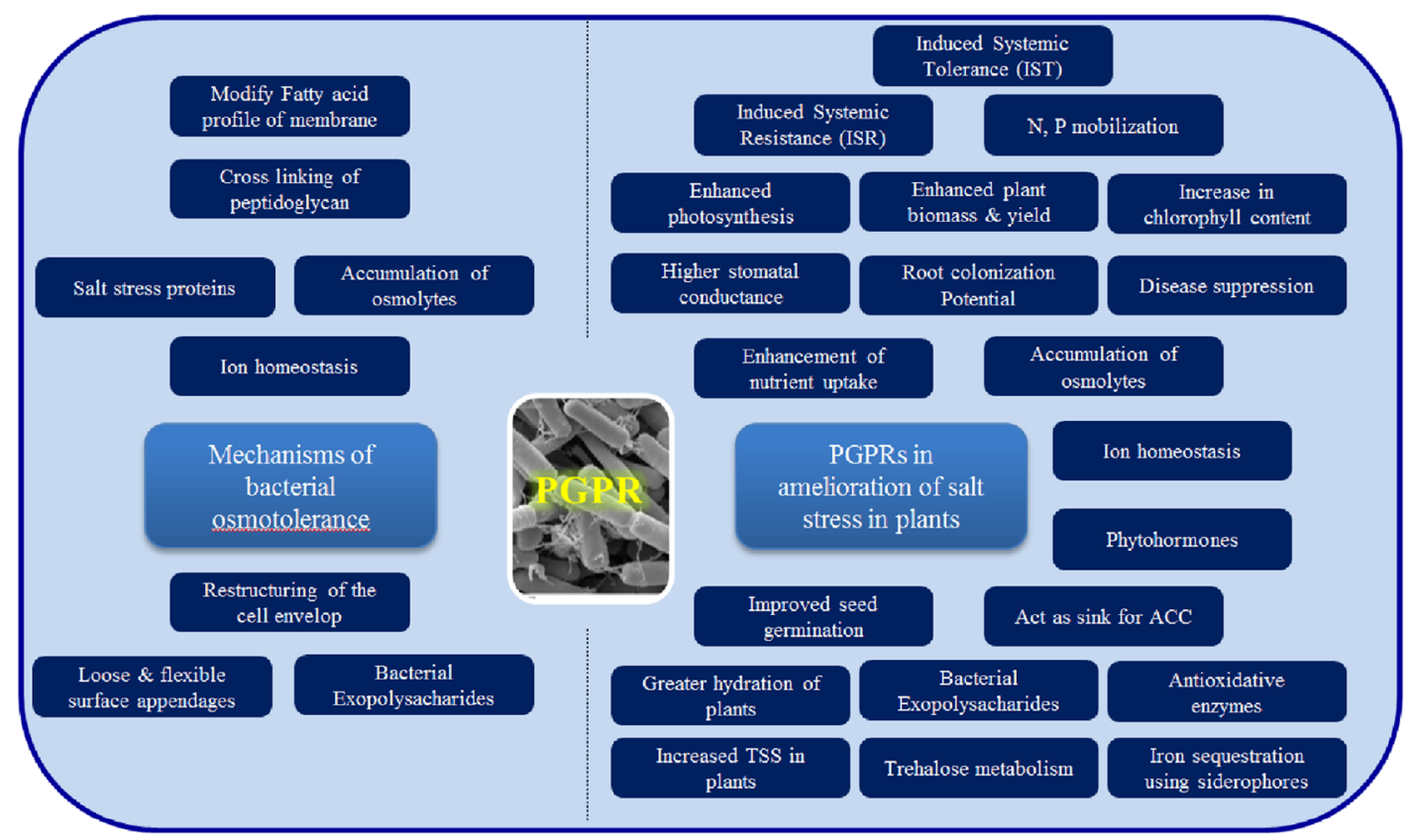

Fig. 2 Plant-growth-promoting rhizobacteria colonise the rhizosphere of plants and promote growth of plants through various means and help mitigate salt stress. Interaction of plant-growth-promoting rhizobacteria with several crops in saline conditions reduced the extent of poor growth

Mayak et al. (2004) observed that, when tomato plants were root bacterised with a suspension of beneficial bacteria, the extent of growth suppression due to salt stress was decreased and the bacterial treated plants accumulated more fresh and dry weights than un-treated plants. Fu et al. (2010) reported that, with increasing salt concentration, growth of eggplant was progressively inhibited, but when the plants were inoculated with the PGPR Pseudomonas sp. DW1, the extent of growth suppression was decreased and these treated plants had greater dry weights than untreated plants, indicating the beneficial role of rhizobacteria in alleviating the debilitating effects of salt stress. Furthermore, PGPRs have been reported to help seed germination in stressed soils and Barassi et al. (2006) reported the same in Azospirillum-inoculated lettuce seeds under salt stress. Applications of biopriming of radish with PGPR strains significantly improved the percentage of seed germination under saline conditions (Kaymak et al. (2009).

Rojas-Tapias et al. (2012) observed enhanced chlorophyll content in maize upon inoculation with Azotobacter strains, revealing a positive effect on growth and plant development. Also in maize and canola, the rhizobacterial treatment increased the total chlorophyll contents ( $\mathrm{a}, \mathrm{b}$ and carotenoids) (Glick et al. 1998; Nadeem et al. 2007). The increase in chlorophyll content may also be the result of an increased photosynthetic leaf area of the plant (Nadeem et al. 2007) by rhizobacteria inoculation, compared with the un-inoculated control where the leaf area was reduced owing to stress (Marcelis et al. 1999). However, it has been reported that, and thus helps plants survive and improve performance in adverse conditions. Beneficial attributes of plant-growth-promoting rhizobacteria (PGPR) towards stress tolerance in crops grown in saline soils are described in the figure

when pepper plants were co-inoculated with $A$. brasilense and Pantoea dispersa, there were higher plant dry matter accumulation under salinity, and it was related to a higher source activity due to higher stomatal conductance and photosynthesis than non-inoculated plants, but without affecting chlorophyll concentration or photosystem II photochemical efficiency (del Amor and Cuadra-Crespo 2012).

\subsection{Bacterial production of phytohormones}

It is most likely that the plant growth hormones of microbial origin in the vicinity of plant roots could evoke a physiological response in the host plant. Production of indole acetic acid, gibberellins and other growth regulators produced by PGPR is believed to support increase root length, root surface area and number of root tips, leading to enhanced uptake of nutrients thereby improving plant health under stress conditions (Egamberdieva and Kucharova 2009). Indole acetic acid production is a relatively common trait of PGPR, and such bacteria is believed to counteract salinity stress in plants. Morphological plant root changes have been observed repeatedly upon Azospirillum inoculation and have been attributed to the production of plant-growth-promoting substances: auxins, cytokinins, and gibberellins, with auxin production being quantitatively the most important (Spaepen et al. 2008). Sadeghi et al. (2012) demonstrated that a Streptomyces isolate increased plant growth in wheat and produced indole acetic acid and auxin in presence of salt. Stimulation of shoot biomass of lettuce plants grown in drying soil by the 
cytokinin-producing PGPR B. subtilis (Arkhipova et al. 2007) implied considerable root-to-shoot cytokinin signalling. Yao et al. (2010) showed that inoculation of P. putida Rs-198 in seeds resulted in increased production of indole acetic acid and inhibited production of abscisic acid, increasing growth parameters in cotton seedlings. Indole acetic acid is a plant growth hormone, while abscisic acid is a well-known stressinducible plant hormone and growth inhibitor. As phytohormone production seems a relatively common trait of PGPR, it is suggested to pay more attention in selecting microbial inoculants with high phytohormone production to potentially ameliorate salt stress.

\subsection{PGPR act as sink for ACC}

In plants grown under salt stress soils, 1-aminocyclopropane1-carboxylate (ACC) levels increase, resulting in high ethylene concentration that ultimately increases plant damage (Botella et al. 2000). Chemical inhibitors of ethylene synthesis, such as cobalt ions and aminoethoxyvinyle glycine, are often used to overcome the problems associated with salt stress. However, these chemicals are not only expensive, but they have harmful effects on the environment (Dodd 2009). Rhizobacteria have been reported to act as a sink for 1aminocyclopropane-1-carboxylate (Saleem et al. 2007), hydrolysing it to ammonia and a-ketobutyrate and thereby lowering the level of ethylene in stressed plants. In the presence of 1-aminocyclopropane-1-carboxylate deaminase producing bacteria, plant 1-aminocyclopropane-1-carboxylate is sequestered and degraded by bacterial cells to supply nitrogen and energy (Mayak et al. 2004), facilitating plant growth under the salinity stress condition (Nadeem et al. 2010; Siddikee et al. 2010). Furthermore, by removing 1-aminocyclopropane-1carboxylate, the bacteria reduce the deleterious effect of ethylene, ameliorating plant stress and promoting plant growth (Glick et al. 2007). The effectiveness of 1aminocyclopropane-1-carboxylate deaminase containing rhizobacteria for enhancing salt tolerance and consequently improving the growth of tomato, rice and various other crops under salt-stress conditions have been well proved (Bal et al. 2013 and Mayak et al. 2004). Siddikee et al. (2010) reported that halotolerant strains of bacteria that belong to different bacterial genera, i.e. Bacillus, Brevibacterium, Planococcus, Zhihengliuella, Halomonas, Exiguobacterium, Oceanimonas, Corynebacterium, Arthrobacter and Micrococcus that were originally isolated from coastal soils, have a real potential to enhance plant growth under saline stress via 1aminocyclopropane-1-carboxylate deaminase activity. The enzyme 1-aminocyclopropane-1-carboxylate deaminase has been found in a wide range of other rhizobacteria as well, such as the genera Achromobacter, Acidovorax, Alcaligenes, Enterobacter, Klebsiella, Methylobacterium, Pseudomonas, Rhizobium and Variovorax (Esquivel-Cote et al. 2010).

\subsection{PGPR-mediated ion homeostasis}

Microbes can alter root uptake of toxic ions and nutrients by altering host physiology or by directly reducing foliar accumulation of toxic ions $\left(\mathrm{Na}^{+}\right.$and $\left.\mathrm{Cl}^{-}\right)$while improving the nutritional status of both macro- $(\mathrm{N}, \mathrm{P}$ and $\mathrm{K}$ ) and micronutrients ( $\mathrm{Zn}, \mathrm{Fe}, \mathrm{Cu}$ and $\mathrm{Mn}$ ), mostly via unknown mechanisms. Potassium plays a key role in plant water stress tolerance and has been found to be the cationic solute responsible for stomatal movements in response to changes in bulk leaf water status (Caravaca et al. 2004). Zhang et al. (2008) reported that inoculation with $B$. subtilis GB03 could mediate the level of salt tolerance in Arabidopsis thaliana through regulation of the potassium transporter HKT1. Certain volatiles emitted by PGPR have been shown to down regulate $H K T 1$ expression in roots but up-regulates it in shoots, orchestring lower $\mathrm{Na}^{+}$levels and recirculation of $\mathrm{Na}^{+}$in the whole plant under salt conditions (Zhang et al. 2008). These results supported the idea that bacteria can mediate the expression of an ion high-affinity $\mathrm{K}^{+}$transporter (AtHKT1) in Arabidopsis under saline condition. PGPR-inoculated plants have been demonstrated to have increased $\mathrm{K}^{+}$concentration, which in turn resulted in a high $\mathrm{K}^{+} / \mathrm{Na}^{+}$ratio leading to their effectiveness in salinity tolerance (Kohler et al. 2009; Nadeem et al. 2013; Rojas-Tapias et al. 2012). Ashraf et al. (2004) found that Azospirillum could restrict $\mathrm{Na}^{+}$ influx into roots. In addition, high $\mathrm{K}^{+} / \mathrm{Na}^{+}$ratios were found in salt-stressed maize in which selectivity for $\mathrm{Na}^{+}, \mathrm{K}^{+}$, and $\mathrm{Ca}^{2+}$ was altered in favour of the plant, upon inoculation with Azospirillum (Hamdia et al. 2004).

Salinity not only reduces $\mathrm{Ca}^{2+}$ and $\mathrm{K}^{+}$availability in plants but also reduces $\mathrm{Ca}^{2+}$ and $\mathrm{K}^{+}$mobility and transport to the growing parts of plants. However, Fu et al. (2010) reported significantly increased $\mathrm{Ca}^{2+}$ in shoots of eggplants inoculated with Pseudomonas when compared to the non-inoculated eggplant under saline conditions. Yao et al. (2010) demonstrated that PGPRs are involved in significantly increasing the cotton's absorbability of $\mathrm{Mg}^{2+}$ and $\mathrm{Ca}^{2+}$ and decreasing the absorption of the $\mathrm{Na}^{+}$. It has also been shown that $\mathrm{Ca}^{2+}$ plays a major role as an early signalling molecule at the onset of salinity.

Salt stress leads to damage to the plant cell membrane and hence increase its permeability resulting in electrolyte leakage and accumulation of it in the surrounding tissues. Inoculation with Rhizobium and Pseudomonas in Zea mays have been reported to lower the electrolyte leakage (Bano and Fatima 2009 and Sandhya et al. 2010). Similar observations were made by Shukla et al. (2012) in Arachis hypogaea, suggesting that PGPR protect the integrity of the plant cell membrane from the detrimental effect of salt. 


\subsection{Accumulation of osmolytes}

Maintaining water homeostasis and the functioning of photosynthetic structures are essential for alleviating the impact of salinity on plant growth and crop yield. One of the most common stress responses in plants is overproduction of different types of compatible organic solutes such as proline and glycine betaine (Serraj and Sinclair 2002). Proline accumulation is a sensitive physiological index of the response of plants to salt and other stresses (Peng et al. 2008) to maintain higher leaf water potential during stress and to keep plants protected against oxidative stress. PGPRs have been demonstrated to enhance plant stress tolerance by contributing to osmolyte accumulation in plants. Increased accumulation of proline has been reported in soybean plants grown under saline conditions upon inoculation with PGPR strains that alleviated salinity stress and improved growth (Han and Lee 2005). Zarea et al. (2012) also reported increased the proline accumulation in wheat upon root colonisation with PGPRs. Azospirillum could also accumulate proline (Bashan 1999; Casanovas et al. 2003) in plants as an osmoprotectant. It is reported that proline protects higher plants against salt/osmotic stresses, not only by adjusting osmotic pressure but also by stabilising many functional units such as complex II electron transport and enzymes such as ribulose bisphosphate carboxylase/oxygenase (RUBISCO) (Makela et al. 2000). Proline also helps the plant cell by stabilising subcellular structures such as membranes and proteins, scavenging free radicals and buffering cellular redox potential under salt stress to alleviate salt stress (Ashraf and Foolad 2007 and Kohler et al. 2009). Increased total soluble sugar (TSS) content of plants under salinity stress is another important defence strategy to cope with salinity stress, and Upadhyay et al. (2012) showed that an increased proline and total soluble sugar in the PGPR-treated wheat plants significantly contributed to their osmotolerance. Similarly, trehalose metabolism in rhizobia also seems important for improving plant growth, yield and adaptation to abiotic stress of leguminous plants (Suarez et al. 2008).

\subsection{Antioxidative enzymes}

Formation of reactive oxygen species upon salt shock in plants brings about damage to lipids, protein and nucleic acids. Reactive oxygen species production is favoured due to over-reduction of photosynthetic electron chain by the limiting of photosynthesis under salinity (Johnson et al. 2003; Hichem et al. 2009). Antioxidants have been reported to have greater resistance to this oxidative damage (Spychalla and Desborough 1990). The activities of the antioxidative enzymes such as catalase, guaicol peroxidase and superoxide dismutase increase under salt stress in plants and a correlation of these enzyme levels and salt tolerance exists (Mittova et al.
2002, 2003). Researches with application of PGPRs have shown significant increase in plants of several of plantdefence-related enzymes, superoxide dismutase, peroxidase, catalase, polyphenol oxidase, phenylalanine ammonia-lyase, lipoxygenase and phenolics (Liang et al. 2011; Nautiyal et al. 2008; Chakraborty et al. 2013). These PGPR-induced antioxidative enzymes are believed to be contributing to the salt stress tolerance in plants also by eliminating hydrogen peroxide from salt-stressed roots (Kim et al. 2005). However, few data are available about the mechanisms involved in bacterialmediated plant antioxidative protection.

6.8 Bacterial extracellular polymeric substance in plant stress alleviation

Extracellular polymeric substance-producing PGPR have been reported to significantly enhance the volume of soil macropores and the rhizosphere soil aggregation, resulting in increased water and fertiliser availability to inoculated plants, which in turn is believed to help plants to better manage the salt shock. The influence of extracellular polymeric substance-producing PGPR on the aggregation of rootadhering soils has been well described (Upadhyay et al. 2011; Alami et al. 2000). PGPR strains that produce bacterial extracellular polymeric substance bind cations including $\mathrm{Na}^{+}$, and it may be envisaged that increasing the population density of extracellular polymeric substance-producing bacteria in the root zone would decrease the content of $\mathrm{Na}^{+}$available for plant uptake, thus help alleviating salt stress in plants growing in saline environments (Geddie et al. 1993). Roberson and Firestone (1992) demonstrated that the extracellular polymeric substance of bacteria possess unique water holding and cementing properties, thus play a vital role in the formation and stabilisation of soil aggregates and regulation of nutrients and water flow across plant roots through biofilm formation.

\subsection{Enhancement of plant nutrient uptake}

Mineral nutritional status of plants greatly affects their ability to adapt to adverse environmental conditions and in particular to abiotic stress factors, impairment of which exacerbates the adverse effects of abiotic stresses. Nutritional imbalance hampers plant growth, development and also the yield. Imbalances may result from the effect of salinity on nutrient availability, competitive uptake, transport or partitioning within the plant or may be caused by physiological inactivation of a given nutrient resulting in an increase in the plant's internal requirement for that essential element (Grattan and Grieve 1994). Crop performance may be adversely affected by salinityinduced nutritional disorders. Nitrogen, in one form or another, accounts for about $80 \%$ of the total mineral nutrients absorbed by plants, and inadequate nitrogen is often a growth-limiting nutritional stress (Marschner 1995). Studies 
indicate that salinity reduces $\mathrm{N}$ uptake/accumulation (Feigin 1985). In addition, it is known that salt stress causes reduction in $\mathrm{P}$ accumulation in plants, which develop P-deficiency symptoms. Salinity reduces phosphate uptake/accumulation in crops grown in soils primarily by reducing phosphate availability (Sharpley et al. 1992). Besides, maintenance of adequate levels of $\mathrm{K}^{+}$is essential for plant survival in saline habitats, and sodium-induced $\mathrm{K}^{+}$deficiency has been implicated in various crops (Botella et al. 1997).

PGPRs have been proved to be vital for circulation of plant nutrients in many ways, thereby reducing the need for chemical fertilisers. Apart from fixing $\mathrm{N}_{2}$, many strains of PGPR can affect plant growth directly by solubilising inorganic phosphate, improving nutrient uptake and mineralising organic phosphate (Dobbelaere et al. 2003; Ogut et al. 2010). Solubilisation of phosphorus in rhizosphere is the most common mode of action implicated in PGPR that increase the nutrient availability to the host plant (Rashid et al. 2004). These rhizobacteria are critical for the transfer of $\mathrm{P}$ from poorly available forms and are important for maintaining $\mathrm{P}$ in readily available pools. Diby et al. (2005b) reported enhanced nutrient mobilisation in the rhizosphere of black pepper and significant uptake of nitrogen $(\mathrm{N})$ and phosphorus $(\mathrm{P})$ in the PGPR-treated black pepper vines that resulted in root proliferation and enhanced plant growth. Strains of rhizobacteria that have efficient phosphorus-solubilising ability even under high saline $\left(60 \mathrm{~g} \mathrm{~L}^{-1} \mathrm{NaCl}\right)$ conditions have been reported (Son et al. 2006; Upadhyay et al. 2011). The damaging effects of $\mathrm{NaCl}$ on wheat seedlings were demonstrated to be reduced by inoculation with $A$. brasilense (Creus et al. 1997). Azospirillum inoculated lettuce seeds had better germination and vegetative growth than non-inoculated controls after being exposed to $\mathrm{NaCl}$ (Barassi et al. 2006). Dardanelli et al. (2008) reported as salt stress affect nodulation during Phaseolus-Rhizobium interaction, a secondary inoculation of the salt-stressed plants with Azospirillum caused an extended exudation of plant flavonoids compared to Rhizobium alone. This co-inoculation of plants with different bacterial strains contributed to relieving of the abiotic stress.

\subsection{PGPR-mediated disease suppression}

In general, competition for nutrients, niche exclusion, induced systemic resistance (ISR) and antifungal metabolites production are the chief modes of biocontrol activity in PGPR (Lugtenberg and Kamilova 2009). Many rhizobacteria have been reported to produce antifungal metabolites like $\mathrm{HCN}$, phenazines, pyrrolnitrin, 2,4-diacetylphloroglucinol, pyoluteorin, viscosinamide and tensin (Bhattacharyya and Jha 2011). Several strains of PGPRs have been demonstrated to exhibit biological control of plant pathogens even in saline soils. Diby et al. (2005a) reported that the population of the biocontrol agent, $P$. fluorescens in the saline rhizospheric soil did not change considerably with increasing salinity in the soil, indicating that the colonisation efficiency of the strain was not affected by the salinity factor. Paul and Nair (2008) ascertained that the osmotolerance mechanisms of the salttolerant PGPRs effectively nullified the detrimental effects of high osmolarity and fully serve as biocontrol agents in crops grown in saline soils. Egamberdieva (2012) reported the repression of cucumber and tomato root rot caused by $F$. solani in salinated soil when the plants were treated with salt tolerant P. chlororaphis strain. PGPR-mediated biocontrol of several plant diseases against an array of pathogens have been reported even under saline conditions (Elmer 2003; Paul and Nair 2008; Rangarajan et al. 2003; Triky-Dotan et al. 2005).

Induced systemic resistance is the enhanced defensive capacity that a plant develops against a broad spectrum of plant pathogens after colonisation of the roots by certain strains of microorganisms (van Loon et al. 1998). Research on these lines has led to the identification of several species of microorganisms with strong activity and microbial components such as lipopolysacharides, flagella, siderophores, cyclic lipopeptides, 2,4-diacetylphloroglucinol, homoserine lactones and certain volatiles (Lugtenberg and Kamilova 2009) as elicitors of induced systemic resistance. Induced systemic resistance in plants by rhizobacteria has been proved against several bacterial, fungal and viral plant diseases (Leeman et al. 1995; Park et al. 2009). Induced systemic resistance involves jasmonate and ethylene signalling within the plant, and these hormones stimulate the host plant's defence responses against a variety of plant pathogens (Glick, 2012). The term induced systemic tolerance (IST) has been proposed for PGPRinduced physical and chemical changes that result in enhanced tolerance to abiotic stress (Sarma et al. 2012). Induced systemic tolerance to salt stress was also noted in a study with Arabidopsis (Zhang et al. 2008) using B. subtilis GB03, a commercial biological control agent. Some of the volatiles organic compounds emitted from Bacillus (Ryu et al. 2004) are believed to be bacterial determinants involved in induced systemic tolerance.

\section{Conclusion}

The costs associated with soil salinity are potentially enormous, and the effects of salinity may impact heavily on agriculture, biodiversity and the environment. As the saline areas under agriculture are increasing every year across the globe, it is of much public concern. Salt-stressed soils are known to suppress the growth of plants. Salinity also disturbs the sustainability of beneficial microorganisms associated with the plant rhizosphere. There is a growing worldwide demand for sound, ecologically compatible and environmentally friendly techniques in saline soil agriculture. Application 
of certain beneficial microorganisms, PGPRs, is an important alternative to some of the traditional agricultural techniques, and it is now widely in practice. PGPRs that live in association with plant-roots offer enhanced plant growth and stress alleviation by various means. Salt-tolerant PGPRs have own mechanisms for osmotolerance and could provide a significant benefit to the plants grown in saline soils, in terms of osmotolerance, better growth, vigour and yield. PGPRs enhance plant growth by several different mechanisms such as asymbiotic $\mathrm{N}_{2}$ fixation, solubilisation of mineral phosphate and other essential nutrients, production of plant hormones and other. Bacterial production of 1-aminocyclopropane-1carboxylate deaminase, induced systemic resistance, IST and control of phytopathogenic microorganisms in the rhizosphere are also modes of support to the plant. PGPRs mitigate salt stress in crops by enhancing osmolyte accumulation in plants, increasing $\mathrm{K}^{+}$concentration and maintaining a high $\mathrm{K}^{+} / \mathrm{Na}^{+}$ ratio and scavenging ROS generated by plants with bacterial antioxidative enzymes, etc. PGPR-mediated saline stress alleviation in plants have been reported in many of crops grown in various geographical locations.

Commercial application of microbial inoculants to improve crop growth and yield in saline environments is a potential strategy for saline soil agriculture. There are several PGPR inoculants currently commercialised that promote growth or control pathogens or induce systemic resistance against pathogens or bring about mitigation of stress tolerance through at least one mechanism. The potential PGPR isolates are formulated using different organic and inorganic carriers either through solid or liquid fermentation technologies. Use of PGPR consortium with known functions that could act synergistically is of interest as they offer multiple modes of action, and temporal or spatial variability. Understanding the interaction between consortium of microbial inoculants and plant systems will pave way to harness more benefits from microbial inoculants for improving plant growth and enhancing tolerance to stress.

\section{References}

Abrol IP, Yadav JSP, Massoud FI (1988) Salt-affected soils and their management. Food and Agriculture Organization of the United Nations, Soils Bull. 39, Rome, Italy

Alami Y, Achouak W, Marol C, Heulin T (2000) Rhizosphere soil aggregation and plant growth promotion of sunflowers by an exopolysaccharide-producing rhizobium sp. strain isolated from sunflower roots. Appl Environ Microbiol 66(8):3393-8. doi:10. 1128/AEM.66.8.3393-3398.2000

Arkhipova TN, Prinsen E, Veselov SU, Martinenko EV, Melentiev AI, Kudoyarova GR (2007) Cytokinin producing bacteria enhance plant growth in drying soil. Plant Soil 292(1-2):305-15. doi:10.1007/ s11104-007-9233-5
Armstrong W, Wright EJ, Lythe S, Gaynard TJ (1985) Plant zonation and the effects of the spring-neap tidal cycle on soil aeration in humber salt marsh. J Ecol 73(3):323-39. doi:10.2307/2259786

Ashraf M, Foolad MR (2007) Roles of glycine betaine and proline in improving plant abiotic stress resistance. Environ Exp Bot 59(2): 206-16. doi:10.1016/j.envexpbot.2005.12.006

Ashraf M, Hasnain S, Berge O, Mahmood T (2004) Inoculating wheat seedlings with exopolysaccharide-producing bacteria restricts sodium uptake and stimulates plant growth under salt stress. Biol Fertil Soils 40(3):157-62. doi:10.1007/s00374-004-0766-y

Bais HP, Weir TL, Perry LG, Gilroy S, Vivanco JM (2006) The role of root exudates in rhizosphere interactions with plants and other organisms. Annu Rev Plant Biol 57(1):233-66. doi:10.1146/ annurev.arplant.57.032905.105159

Bal HB, Nayak L, Das S, Adhya TK (2013) Isolation of ACC deaminase producing PGPR from rice rhizosphere and evaluating their plant growth promoting activity under salt stress. Plant Soil 366(1-2):93105. doi:10.1007/s11104-012-1402-5

Bano A, Fatima M (2009) Salt tolerance in Zea mays (L) following inoculation with Rhizobium and Pseudomonas. Biol Fertil Soils 45(4):405-13. doi:10.1007/s00374-008-0344-9

Barassi CA, Ayrault G, Creus CM, Sueldo RJ, Sobrero MT (2006) Seed inoculation with Azospirillum mitigates $\mathrm{NaCl}$ effects on lettuce. Sci Hortic-Amst 109(1):8-14. doi:10.1016/j.scienta.2006.02.025

Bashan Y (1999) Interactions of Azospirillum spp. in soils: a review. Biol Fertil Soils 29(3):246-56. doi:10.1007/s003740050549

Bharathkumar S, Paul D, Nair S (2008) Microbial diversity of culturable heterotrophs in the rhizosphere of salt marsh grass, Porteresia coarctata (Tateoka) in a mangrove ecosystem. J Basic Microbiol 48(1):10-5. doi:10.1002/jobm.200700282

Bhattacharyya PN, Jha DK (2011) Plant growth-promoting rhizobacteria (PGPR): emergence in agriculture. World J Microbiol Biotechnol 28(4):1327-1350. doi:10.1007/s11274-011-0979-9

Borneman J, Skroch PW, O'Sullivan KM, Palus JA, Rumjanek NG, Jansen JL et al (1996) Molecular microbial diversity of an agricultural soil in Wisconsin. Appl Environ Microbiol 62(6):1935-43

Bot AJ, Nachtergaele FO, Young A (2000) Land resource potential and constraints at regional and country levels. World Soil Resources Reports. 90, Land and Water Development Division, Food and Agriculture Organization of the United Nations, Rome, Italy

Botella MA, del Amor FM, Amoros A, Serrano M, Martinez V, Cerda A (2000) Polyamine, ethylene and other physico-chemical parameters in tomato (Lycopersicon esculentum) fruits as affected by salinity. Physiol Plant 109(4):428-34. doi:10.1034/j.1399-3054.2000. 100409.x

Botella MA, Martinez V, Pardines J, Cerdá A (1997) Salinity induced potassium deficiency in maize plants. J Plant Physiol 150(1-2):200 05. doi:10.1016/S0176-1617(97)80203-9

Braud A, Jezequel K, Bazot S, Lebeau T (2009) Enhanced phytoextraction of an agricultural $\mathrm{Cr}$ - and $\mathrm{Pb}$-contaminated soil by bioaugmentation with siderophore-producing bacteria. Chemosphere 74(2):280-6. doi: 10.1016/j.chemosphere.2008.09.013

Burrow DP, Surapaneni A, Rogers ME, Olsson KA (2002) Groundwater use in forage production: the effect of saline-sodic irrigation and subsequent leaching on soil sodicity. Aust J Exp Agric 42(3):237247. doi:10.1071/EA00157

Caravaca F, Figueroa D, Barea JM, Azcon-Aguilar C, Roldan A (2004) Effect of mycorrhizal inoculation on nutrient acquisition, gas exchange, and nitrate reductase activity of two Mediterraneanautochthonous shrub species under drought stress. J Plant Nutr 27(1):57-74. doi:10.1081/PLN-120027547

Casanovas EM, Barassi CA, Andrade FH, Sueldo RJ (2003) Azospirilluminoculated maize plant responses to irrigation restraints imposed during flowering. Cereal Res Commun 31(3-4):395-402

Chakraborty N, Ghosh R, Ghosh S, Narula K, Tayal R, Datta A, Chakraborty S (2013) Reduction of oxalate levels in tomato fruit 
and consequent metabolic remodeling following overexpression of a fungal oxalate decarboxylase ${ }^{1[\mathrm{~W}]}$. Plant Physiol 162(1):364-78. doi: 10.1104/pp. 112.209197

Chandler SF, Thorpe TA (1986) Variation from plant tissue cultures: biotechnological application to improving salinity tolerance. Biotechnol Adv 4(1):117-35. doi:10.1016/0734-9750(86)90007-8

Chinnusamy V, Jagendorf A, Zhu JK (2005) Understanding and improving salt tolerance in plants. Crop Sci 45(2):437-48. doi:10.2135/ cropsci2005.0437

Creus CM, Sueldo RJ, Barassi CA (1997) Shoot growth and water status in Azospirillum-inoculated wheat seedlings grown under osmotic and salt stresses ${ }^{(1)}$. Plant Physiol Biochem 35(12): 939-944

Dardanelli MS, de Cordoba FJF, Espuny MR, Carvajal MAR, Diaz MES, Serrano AMG et al (2008) Effect of Azospirillum brasilense coinoculated with rhizobium on Phaseolus vulgaris flavonoids and Nod factor production under salt stress. Soil Biol Biochem 40(11): 2713-21. doi:10.1016/j.soilbio.2008.06.016

del Amor FM, Cuadra-Crespo P (2012) Plant growth-promoting bacteria as a tool to improve salinity tolerance in sweet pepper. Funct Plant Biol 39(1):82-90. doi:10.1071/FP11173

Diby P, Bharathkumar S, Sudha N (2005a) Osmotolerance in biocontrol strain of pseudomonas pseudoalcaligenes MSP-538: a study using osmolyte, protein and gene expression profiling. Ann Microbiol 55(4):243-47

Diby P, Sarma YR, Srinivasan V, Anandaraj M (2005b) Pseudomonas fluorescens mediated vigour in black pepper (piper nigrum $\mathrm{L}$.) under green house cultivation. Ann Microbiol 55(3):171-74

Dimkpa C, Weinand T, Asch F (2009) Plant-rhizobacteria interactions alleviate abiotic stress conditions. Plant Cell Environ 32(12):168294. doi:10.1111/j.1365-3040.2009.02028.x

Dobbelaere S, Vanderleyden J, Okon Y (2003) Plant growth-promoting effects of diazotrophs in the rhizosphere. Crit Rev Plant Sci 22(2): 107-49. doi:10.1080/713610853

Dodd IC (2009) Rhizosphere manipulations to maximize 'crop per drop' during deficit irrigation. J Exp Bot 60(9):2454-59. doi:10.1093/jxb/ erp192

Egamberdieva D, Kucharova Z (2009) Selection for root colonising bacteria stimulating wheat growth in saline soils. Biol Fertil Soils 45(6):563-71. doi:10.1007/s00374-009-0366-y

Egamberdieva D (2012) Pseudomonas chlororaphis: a salt-tolerant bacterial inoculant for plant growth stimulation under saline soil conditions. Acta Physiol Plant 34(2):751-56. doi:10.1007/s11738-011-0875-9

Egamberdieva D (2011) Survival of pseudomonas extremorientalis TSAU20 and $P$. Chlororaphis TSAU13 in the rhizosphere of common bean (Phaseolus vulgaris) under saline conditions. Plant Soil Environ 57(3):122-7

El-Fouly MM, Zeinab MM, Zeinab AS et al (2001) Micronutrient sprays as a tool to increase tolerance of faba bean and wheat plants to salinity. In: Horst WJ (ed) Plant nutrition, 92. Springer, Netherlands, pp 422-423. doi:10.1007/0-306-47624-X_204

Elmer WH (2003) Local and systemic effects of $\mathrm{NaCl}$ on root composition, rhizobacteria, and Fusarium crown and root rot of asparagus. Phytopathol 93(2):186-92. doi:10.1094/PHYTO.2003.93.2.186

Esquivel-Cote R, Ramirez-Gama RM, Tsuzuki-Reyes G, OrozcoSegovia A, Huante P (2010) Azospirillum lipoferum strain AZm5 containing 1-aminocyclopropane-1-carboxylic acid deaminase improves early growth of tomato seedlings under nitrogen deficiency. Plant Soil 337(1-2):65-75. doi:10.1007/s11104-010-0499-7

The Food and Agriculture Organization of the United Nations (FAO) (2002) Crops and drops: making the best use of water for agriculture. FAO, Rome, Italy, http://www.fao.org/docrep/w5146e/ w5146e0a.htm

The Food and Agriculture Organization of the United Nations (FAO) (1988) Salt-affected soils and their management. Soils Bulletin, 39, Rome, Italy, http://www.fao.org/docrep/x5871e/x5871e04.htm
The Food and Agriculture Organization of the United Nations (FAO) (2005) Salt-affected soils from sea water intrusion: strategies for rehabilitation and management. Report of the regional workshop. Bangkok, Thailand, http://www.fao.org/docrep/008/ae551e/ ae551e00.HTM

Feigin A (1985) Fertilization management of crops irrigated with saline water. Plant Soil 89:285-99. doi:10.1007/BF02182248

Flowers TJ, Yeo AR (1995) Breeding for salinity resistance in crop plants: where next? Aus J Plant Physiol 22(6):875-84. doi:10. 1071/PP9950875

Francius G, Polyakov P, Merlin J, Abe Y, Ghigo JM, Merlin C, Beloin C, Duval JF (2011) Bacterial surface appendages strongly impact nanomechanical and electrokinetic properties of Escherichia coli cells subjected to osmotic stress. PloS one 6(5):e20066. doi:10. 1371/journal.pone.0020066

Fu QL, Liu C, Ding NF, Lin YC, Guo B (2010) Ameliorative effects of inoculation with the plant growth-promoting rhizobacterium Pseudomonas sp. DW1 on growth of eggplant (Solanum melongena L.) seedlings under salt stress. Agr Water Manag 97(12):1994-2000. doi:10.1016/j.agwat.2010.02.003

Geddie JL, Sutherland IW (1993) Uptake of metals by bacterial polysaccharides. J Appl Bacteriol 74(4):467-72. doi:10.1111/j.1365-2672. 1993.tb05155.x

Georg J, Voss B, Scholz I, Mitschke J, Wilde A, Hess W (2009) Evidence for a major role of antisense RNAs in cyanobacterial gene regulation. Mol Syst Biol 5:305. doi:10.1038/msb.2009.63

Ghassemi AJ, Jakeman HA (1995) Nix salinisation of land and water resources human causes, extent, management and case studies. $\mathrm{CAB}$ International, Wallingford

Glick BR (2012) Plant growth-promoting bacteria: mechanisms and applications. Sci 2012:15. doi:10.6064/2012/963401

Glick BR, Cheng Z, Czarny J, Duan J (2007) Promotion of plant growth by ACC deaminase-producing soil bacteria. Eur J Plant Pathol 119(3):329-39. doi:10.1007/s10658-007-9162-4

Glick BR, Penrose DM, Li J (1998) A model for the lowering of plant ethylene concentrations by plant growth-promoting bacteria. J Theor Biol 190(1):63-8. doi:10.1006/jtbi.1997.0532

Graham PH (1992) Stress tolerance in Rhizobium and Brady-rhizobium, and nodulation under adverse soil conditions. Can J Microbiol 38(6):475-84. doi:10.1139/m92-079

Grattan SR, Grieve CM (1994) Mineral nutrient acquisition and response by plants grown in saline environments. In: Pessarakli M (ed) Handbook of Plant and Crop Stress, 2nd edn. Marcel Dekker, New York, pp 203-26. doi:10.1201/ 9780824746728.ch9

Grover M, Ali SZ, Sandhya V, Rasul A, Venkateswarlu B (2011) Role of microorganisms in adaptation of agriculture crops to abiotic stresses. World J Microbiol Biotechnol 27(5):1231-40. doi:10.1007/s11274010-0572-7

Guillot A, Obis D, Mistou MY (2000) Fatty acid membrane composition and activation of glycine-betaine transport in Lactococcus lactis subjected to osmotic stress. Int J Food Microbiol 55(1-3):47-51. doi:10.1016/S0168-1605(00)00193-8

Hamaoui B, Abbadi JM, Burdman S, Rashid A, Sarig S, Okon Y (2001) Effects of inoculation with Azospirillum brasilense on chickpeas (Cicer arietinum) and faba beans (Vicia faba) under different growth conditions. Agronomie 21(6-7):553-60. doi: 10.1051/agro:2001144

Hamdia MBE, Shaddad MAK, Doaa MM (2004) Mechanisms of salt tolerance and interactive effects of Azospirillum brasilense inoculation on maize cultivars grown under salt stress conditions. Plant Growth Regul 44(2):165-74. doi:10.1023/B:GROW.0000049414. 03099.9b

Han HS, Lee KD (2005) Physiological responses of soybean inoculation of Bradyrhizobium japonicum PGPR in saline soil conditions. Res J Agri Biol Sci 1(3):216-21 
Hasegawa PM, Bressan RA, Zhu JK, Bohnert HJ (2000) Plant cellular and molecular responses to high salinity. Annu Rev Plant Physiol Plant Mol Biol 51:463-99. doi:10.1146/annurev.arplant.51.1.463

Hayat R, Ali S, Amara U, Khalid R, Ahmed I (2010) Soil beneficial bacteria and their role in plant growth promotion: a review. Ann Microbiol 60(4):579-98. doi:10.1007/s13213-010-0117-1

Hichem H, Naceur EA, Mounir D (2009) Effects of salt stress on photosynthesis, PSII photochemistry and thermal energy dissipation in leaves of two corn (Zea mays L.) varieties. Photosynthetica 47(4): 517-26. doi:10.1007/s11099-009-0077-5

Howell TA (2001) Enhancing water use efficiency in irrigated agriculture. Agron J 93(2):281-9. doi:10.2134/agronj2001.932281x

Ibekwe AM, Papiernik SK, Yang CH (2010) Influence of soil fumigation by methyl bromide and methyl iodide on rhizosphere and phyllosphere microbial community structure. J Environ Sci Health B 45(5):427-36. doi:10.1080/03601231003800131

Jastrow JD, Miller RM (1991) Methods for assessing the effects of biota on soil structure. Agric Ecosyst Environ 34(1-4):279-303. doi:10. 1016/0167-8809(91)90115-E

Jha M, Chourasia S, Sinha S (2013) Microbial consortium for sustainable rice production. Agroecol Sustain Food Syst 37(3):340-62. doi:10. 1080/10440046.2012.672376

Jiang HC, Dong HL, Yu BS, Liu XQ, Li YL, Ji SS, Zhang CL (2007) Microbial response to salinity change in Lake Chaka, a hypersaline lake on Tibetan plateau. Environ Microbiol 9(10):2603-21. doi:10. 1111/j.1462-2920.2007.01377.x

Jofre E, Fischer S, Rivarola V, Balegno H, Mori G (1998) Saline stress affects the attachment of Azospirillum brasilense $\mathrm{Cd}$ to maize and wheat roots. Can J Microbiol 44(5):416-22. doi:10.1139/w98-024

Johnson HE, Broadhurst D, Goodacre R, Smith AR (2003) Metabolic fingerprinting of salt-stressed tomatoes. Phytochemistry 62(6):919 28. doi:10.1016/S0031-9422(02)00722-7

Kaymak HC, Guvenc I, Yarali F, Donmez MF (2009) The effects of biopriming with PGPR on germination of radish (Raphanus sativus L.) seeds under saline conditions. Turk J Agric For 33(2):173-79

Kim SY, Lim JH, Park MR, Kim YJ, Park TI, Se YW, Choi KG, Yun SJ (2005) Enhanced antioxidant enzymes are associated with reduced hydrogen peroxide in barley roots under saline stress. J Biochem Mol Biol 38(2):218-24. doi:10.5483/BMBRep.2005.38.2.218

Klein W, Weber MH, Marahiel MA (1999) Cold shock response of bacillus subtilis: isoleucine-dependent switch in the fatty acid branching pattern for membrane adaptation to low temperatures. J Bacteriol 181(17):5341-9

Kloepper JW, Schroth MN (1978) Plant growth-promoting rhizobacteria on radish. In: Proceedings of the 4th International Conference on Plant Pathogenic Bacteria. Ed. Station de pathologic Vegetal et Phytobacteriologic. Agners, France 2:879-82

Kohler J, Caravaca F, Roldan A (2010) An AM fungus and a PGPR intensify the adverse effects of salinity on the stability of rhizosphere soil aggregates of Lactuca sativa. Soil Biol Biochem 42(3):429-34. doi:10.1016/j.soilbio.2009.11.021

Kohler J, Hernandez JA, Caravaca F, Roldan A (2009) Induction of antioxidant enzymes is involved in the greater effectiveness of a PGPR versus AM fungi with respect to increasing the tolerance of lettuce to severe salt stress. Environ Exp Bot 65(2-3):245-52. doi: 10.1016/j.envexpbot.2008.09.008

Kotuby-Amacher J, Koenig K, Kitchen B (2000) Salinity and plant tolerance. https://extension.usu.edu/files/publications/publication/ AG-SO-03.pdf.

Lamosa P, Martins LO, Da Costa MS, Santos H (1998) Effects of temperature, salinity, and medium composition on compatible solute accumulation by thermococcus spp. Appl Environ Microbiol 64(10):3591-8

Larcher W. (1980) Physiological plant ecology: ecophysiology and stress physiology of functional groups, 2nd edn. SpringerVerlag, Berlin
Leeman M, Van Pelt JA, Den Ouden FM, Heinsbroek M, Bakker PAHM, Schippers B (1995) Induction of systemic resistance against Fusarium wilt of radish by lipopolysaccharides of pseudomonas fluorescens. Phytopathol 85(9):1021-27

Li YQ, Zhao HL, Yi XY, Zuo XA, Chen YP (2006) Dynamics of carbon and nitrogen storages in plant-soil system during desertification process in horqin sandy land. Huan Jing Ke Xue 27(4): $635-40$

Liu Y, Gao W, Wang Y, Wu L, Liu X, Yan T et al (2005) Transcriptome analysis of Shewanella oneidensis MR-1 in response to elevated salt conditions. J Bacteriol 187(7):2501-7. doi:10.1128/JB.187.7.25012507.2005

Lugtenberg B, Kamilova F (2009) Plant-growth-promoting rhizobacteria. Annu Rev Microbiol 63:541-56. doi:10.1146/annurev.micro.62. 081307.162918

Makela A, Landsberg J, Ek AR, Burk TE, Ter-Mikaelian M, Agren GI et al (2000) Process-based models for forest ecosystem management: current state of the art and challenges for practical implementation. Tree Physiol 20(5-6):289-98. doi:10.1023/A:1004295714181

Malik KAB, Rakhshanda S, Mehnaz G, Rasul MS, Mirza S (1997) Association of nitrogen-fixing plant-growth-promoting rhizobacteria (PGPR) with kallar grass and rice. Plant Soil 194(12):37-44. doi:10.1023/A:1004742713538

Marcelis LFM, Van Hooijdonk J (1999) Effect of salinity on growth, water use and nutrient use in radish (Raphanus sativus L.). Plant Soil 215(1):57-64. doi:10.1023/A:1004742713538

Marschner H (1995) Mineral nutrition of higher plant (second ed.) Academic Press, New York 889 pp.

Marulanda A, Azcon R, Chaumont F, Ruiz-Lozano JM, Aroca R (2010) Regulation of plasma membrane aquaporins by inoculation with a bacillus megaterium strain in maize (Zea mays L.) plants under unstressed and salt-stressed conditions. Planta 232(2):533-43. doi 10.1007/s00425-010-1196-8

Mayak S, Tirosh T, Glick BR (2004) Plant growth-promoting bacteria that confer resistance to water stress in tomatoes and peppers. Plant Sci 166(2):525-30. doi:10.1016/j.plantsci.2003.10.025

Meloni DA, Oliva MA, Martinez CA, Cambraia J (2003) Photosynthesis and activity of superoxide dismutase, peroxidase and glutathione reductase in cotton under salt stress. Environ Exp Bot 49(1):69-76. doi:10.1016/S0098-8472(02)00058-8

Mittova V, Tal M, Volokita M, Guy M (2002) Salt stress induces upregulation of an efficient chloroplast antioxidant system in the salttolerant wild tomato species Lycopersicon pennellii but not in the cultivated species. Physiol Plant 115(3):393-400. doi:10.1034/j. 1399-3054.2002.1150309.x

Mittova V, Tal M, Volokita M, Guy M (2003) Up-regulation of the leaf mitochondrial and peroxisomal antioxidative systems in response to salt-induced oxidative stress in the wild salt-tolerant tomato species Lycopersicon pennellii. Plant Cell Environ 26(6):845-56. doi:10. 1046/j.1365-3040.2003.01016.x

Munns R, Tester M (2008) Mechanisms of salinity tolerance. Annu Rev Plant Biol 59:651-81. doi:10.1146/annurev.arplant.59.032607.092911

Nabti E, Sahnoune M, Ghoul M, Fischer D, Hofmann A, Rothballer M et al (2010) Restoration of growth of durum wheat (Triticum durum var. waha) under saline conditions due to inoculation with the rhizosphere bacterium Azospirillum brasilense $\mathrm{NH}$ and extracts of the marine alga Ulva lactuca. J Plant Growth Regul 29(1):6-22. doi: 10.1007/s00344-009-9107-6

Nadeem SM, Shaharoona B, Arshad M, Crowley DE (2012) Population density and functional diversity of plant growth promoting rhizobacteria associated with avocado trees in saline soils. Appl Soil Ecol 62:147-54. doi:10.1016/j.apsoil.2012.08.005

Nadeem SM, Zahir ZA, Naveed M, Arshad M (2007) Preliminary investigations on inducing salt tolerance in maize through inoculation with rhizobacteria containing ACC deaminase activity. Can J Microbiol 53(10):1141-9. doi:10.1139/W07-081 
Nadeem SM, Zahir ZA, Naveed M, Asghar HN, Arshad M (2010) Rhizobacteria capable of producing ACC-deaminase may mitigate salt stress in wheat. Soil Sci Soc Am J 74(2):533-42. doi:10.2136/ sssaj2008.0240

Nadeem SM, Zahir ZA, Naveed M, Nawaz S (2013) Mitigation of salinityinduced negative impact on the growth and yield of wheat by plant growth-promoting rhizobacteria in naturally saline conditions. Ann Microbiol 63(1):225-32. doi:10.1007/s13213-012-0465-0

Nautiyal CS, Govindarajan R, Lavania M, Pushpangadan P (2008) Novel mechanism of modulating natural antioxidants in functional foods: Involvement of plant growth promoting rhizobacteria NRRL B-30488. J Agr Food Chem 56(12):4474-81. doi:10.1021/ jf073258i

Nelson DR, Mele PM (2007) Subtle changes in rhizosphere microbial community structure in response to increased boron and sodium chloride concentrations. Soil Biol Biochem 39(1):340-51. doi:10. 1016/j.soilbio.2006.08.004

Nie M, Zhang XD, Wang JQ, Jiang LF, Yang J, Quan ZX, Cui XH, Fang CM, Li B (2009) Rhizosphere effects on soil bacterial abundance and diversity in the Yellow River Deltaic ecosystem as influenced by petroleum contamination and soil salinization. Soil Biol Biochem 41(12):2535-42. doi:10.1016/j.soilbio.2009.09.012

Ogut M, Er F, Kandemir N (2010) Phosphate solubilization potentials of soil Acinetobacter strains. Biol Fertil Soils 46(7):707-15. doi:10. 1007/s00374-010-0475-7

Omar SA, Abdel-Sater MA, Khallil AM, Abdalla MH (1994) Growth and enzyme activities of fungi and bacteria in soil salinized with sodium chloride. Folia Microbiol 39(1):23-28. doi:10.1007/BF02814524

Ondrasek G, Rengel Z, Romic D, Savic R (2010) Environmental salinisation processes in agro-ecosystem of neretva river estuary. Novenytermeles 59:223-226

Parida AK, Das AB (2005) Salt tolerance and salinity effects on plants: a review. Ecotox Environ Safe 60(3):324-49. doi:10.1016/j.ecoenv. 2004.06.010

Park KS, Paul D, Kim JS, Park JW (2009) L-Alanine augments rhizobacteria-induced systemic resistance in cucumber. Folia Microbiol (Praha) 54(4):322-6. doi:10.1007/s12223-009-0041-6

Patel D, Jha CK, Tank N, Saraf M (2012) Growth enhancement of chickpea in saline soils using plant growth-promoting rhizobacteria. J Plant Growth Regul 31(1):53-62. doi:10.1007/s00344-011-9219-7

Paul D, Dineshkumar N, Nair S (2006) Proteomics of a plant growthpromoting rhizobacterium, Pseudomonas fluorescens MSP-393, subjected to salt shock. World J Microb Biot 22(4):369-74. doi: 10.1007/s11274-005-9043-y

Paul D, Nair S (2008) Stress adaptations in a plant growth promoting rhizobacterium (PGPR) with increasing salinity in the coastal agricultural soils. J Basic Microbiol 48(5):378-84. doi:10.1002/jobm. 200700365

Paul D (2013) Osmotic stress adaptations in rhizobacteria. J Basic Microbiol 53(2):101-10. doi:10.1002/jobm.201100288

Paul D, Sarma YR (2006) Plant growth promoting rhizobacteria [PGPR] mediated root proliferation in Black pepper (Piper nigrum L.) as evidenced through GS Root software. Arch Phytopathol Plant Prot 39(4):311-314. doi:10.1080/03235400500301190

Peng YL, Gao ZW, Gao Y, Liu GF, Sheng LX, Wang DL (2008) Ecophysiological characteristics of alfalfa seedlings in response to various mixed salt-alkaline stresses. J Integr Plant Biol 50(1):29-39. doi:10.1111/j.1744-7909.2007.00607.x

Piuri M, Sanchez-Rivas C, Ruzal SM (2005) Cell wall modifications during osmotic stress in Lactobacillus casei. J Appl Microbiol 98(1):84-95. doi:10.1111/j.1365-2672.2004.02428.x

Porcel R, Aroca R, Ruiz-Lozano JM (2012) Salinity stress alleviation using arbuscular mycorrhizal fungi: a review. Agron Sustain Dev 32(1):181-200. doi:10.1007/s13593-011-0029-x

Postel SL (1998) Water for food production: will there be enough in 2025? Bioscience 48(8):629-637. doi:10.2307/1313422
Principe A, Alvarez F, Castro MG, Zachi L, Fischer SE, Mori GB, Jofre E (2007) Biocontrol and PGPR features in native strains isolated from saline soils of Argentina. Curr Microbiol 55(4):314-22. doi:10. 1007/s00284-006-0654-9

Rana G, Katerji N (2000) Measurement and estimation of actual evapotranspiration in the field under Mediterranean climate: a review. Eur J Agron 13:125-153. doi:10.1016/S1161-0301(00)00070-8

Rangarajan S, Saleena LM, Vasudevan P, Nair S (2003) Biological suppression of rice diseases by Pseudomonas spp. under saline soil conditions. Plant Soil 251(1):73-82. doi:10.1023/ A: 1022950811520

Rashid N, Imanaka H, Fukui T, Atomi H, Imanaka T (2004) Presence of a novel phosphopentomutase and a 2-deoxyribose 5-phosphate aldolase reveals a metabolic link between pentoses and central carbon metabolism in the hyperthermophilic archaeon thermococcus kodakaraensis. J Bacteriol 186(13):4185-91. doi:10.1128/JB.186. 13.4185-4191.2004

Rietz DN, Haynes RJ (2003) Effects of irrigation-induced salinity and sodicity on soil microbial activity. Soil Biol Biochem 35(6):845-54. doi:10.1016/S0038-0717(03)00125-1

Roberson EB, Firestone MK (1992) Relationship between desiccation and exopolysaccharide production in a soil pseudomonas sp. Appl Environ Microbiol 58(4):1284-91

Rodriguez H, Fraga R (1999) Phosphate solubilizing bacteria and their role in plant growth promotion. Biotechnol Adv 17(4-5):319-39. doi:10.1016/S0734-9750(99)00014-2

Rodriguez R, Redman R (2008) More than 400 million years of evolution and some plants still can't make it on their own: plant stress tolerance via fungal symbiosis. J Exp Bot 59(5):1109-14. doi:10.1093/ jxb/erm342

Rojas-Tapias D, Moreno-Galvan A, Pardo-Diaz S, Obando M, Rivera D, Bonilla R (2012) Effect of inoculation with plant growth-promoting bacteria (PGPB) on amelioration of saline stress in maize (Zea mays). Appl Soil Ecol 61:264-72. doi:10.1016/j.apsoil.2012.01.006

Romic D, Ondrasek G, Romic M, Josip B, Vranjes M, Petosic D (2008) Salinity and irrigation method affect crop yield and soil quality in watermelon (Citrullus Lanatus L.) growing. Irrig Drain 57(4):4639. doi:10.1002/ird.358

Rowell DL (1994) Soil science: methods and applications. Longman Group Ltd., UK

Ryu CM, Farag MA, Hu CH, Reddy MS, Kloepper JW, Pare PW (2004) Bacterial volatiles induce systemic resistance in Arabidopsis. Plant Physiol 134(3):1017-26. doi:10.1104/pp. 103.026583

Sadeghi A, Karimi E, Dahaji PA, Javid MG, Dalvand Y, Askari H (2012) Plant growth promoting activity of an auxin and siderophore producing isolate of Streptomyces under saline soil conditions. World J Microb Biot 28(4):1503-9. doi:10.1007/ s11274-011-0952-7

Salama ZA, Shaaban MM, Abou El-Nour EA (1996) Effect of iron foliar application on increasing tolerance of maize seedlings to saline irrigation water. Egypt J Appl Sci 11(1):169-175

Saleem M, Arshad M, Hussain S, Bhatti AS (2007) Perspective of plant growth promoting rhizobacteria (PGPR) containing ACC deaminase in stress agriculture. J Ind Microbiol Biot 34(10):635-48. doi: 10.1007/s10295-007-0240-6

Sandhya V, Ali SZ, Grover M, Reddy G, Venkateswarlu B (2010) Effect of plant growth promoting Pseudomonas spp. on compatible solutes, antioxidant status and plant growth of maize under drought stress. Plant Growth Regul 62(1):21-30. doi:10.1007/s10725-0109479-4

Sandhya V, ASK Z, Grover M, Reddy G, Venkateswarlu B (2009) Alleviation of drought stress effects in sunflower seedlings by the exopolysaccharides producing Pseudomonas putida strain GAPP45. Biol Fertil Soils 46(1):17-26. doi:10.1007/s00374-009-0401-Z

Saravanakumar D, Samiyappan R (2007) ACC deaminase from Pseudomonas fluorescens mediated saline resistance in groundnut 
(Arachis hypogea) plants. J Appl Microbiol 102(5):1283-92. doi: 10.1111/j.1365-2672.2006.03179.x

Sardinha M, Muller T, Schmeisky H, Joergensen RG (2003) Microbial performance in soils along a salinity gradient under acidic conditions. Appl Soil Ecol 23(3):237-44. doi:10.1016/S0929-1393(03)00027-1

Sarma BK, Yadav SK, Singh DP, Singh HB (2012) Rhizobacteria mediated induced systemic tolerance in plants: prospects for abiotic stress management. In: Maheshwari DK (ed) Bacteria in agrobiology: stress management. Springer Berlin, Heidelberg, pp 225-238. doi: 10.1007/978-3-642-23465-1 11

Selvakumar G, Joshi P, Mishra PK, Bisht JK, Gupta HS (2009) Mountain aspect influences the genetic clustering of psychrotolerant phosphate solubilizing Pseudomonads in the Uttarakhand Himalayas. Curr Microbiol 59(4):432-8. doi:10.1007/s00284-009-9456-1

Serraj R, Sinclair TR (2002) Osmolyte accumulation: can it really help increase crop yield under drought conditions? Plant Cell Environ 25(2):333-41. doi:10.1046/j.1365-3040.2002.00754.x

Shabala S (2009) Salinity and programmed cell death: unravelling mechanisms for ion specific signalling. J Exp Bot 60(3):709-12. doi:10. 1093/jxb/erp013

Shannon MC, Grieve CM (1999) Tolerance of vegetable crops to salinity. Sci Hortic 78(1-4):5-38. doi:10.1016/S0304-4238(98)00189-7

Sharpley AN, Meisinger JJ, Power JF, Suarez DL (1992) Root extraction of nutrients associated with long-term soil management. In: Hatfiedl JL and Stewart BA (Ed.), Limitations to plant growth, Adv Soil Sci 19:151-217. Springer, New York, USA, http://dx.doi.org/10.1007/ 978-1-4612-2894-3_6

Shiklomanov IA, Rodda JC (2003) World water resources at the beginning of the twenty-first century. Cambridge University Press, Cambridge

Shukla PS, Agarwal PK, Jha B (2012) Improved salinity tolerance of Arachis hypogaea (L.) by the interaction of halotolerant plantgrowth-promoting rhizobacteria. J Plant Growth Regul 31(2):195206. doi:10.1007/s00344-011-9231-y

Siddikee MA, Chauhan PS, Anandham R, Han GH, Sa T (2010) Isolation, characterization, and use for plant growth promotion under salt stress, of ACC deaminase-producing halotolerant bacteria derived from coastal soil. J Microbiol Biotechnol 20(11):1577-84. doi:10.4014/jmb.1007.07011

Singleton PW, Bohlool BB (1984) Effect of salinity on nodule formation by soybean. Plant Physiol 74(1):72-6. doi:10.1104/pp. 74.1.72

Son HJ, Park GT, Cha MS, Heo MS (2006) Solubilization of insoluble inorganic phosphates by a novel salt- and $\mathrm{pH}$-tolerant Pantoea agglomerans R-42 isolated from soybean rhizosphere. Bioresour Technol 97(2):204-10. doi:10.1016/j.biortech.2005.02.021

Spaepen S, Dobbelaere S, Croonenborghs A, Vanderleyden J (2008) Effects of Azospirillum brasilense indole-3-acetic acid production on inoculated wheat plants. Plant Soil 312(1-2):15-23. doi:10.1007/ s11104-008-9560-1

Spychalla JP, Desborough SL (1990) Superoxide dismutase, catalase, and alpha-tocopherol content of stored potato tubers. Plant Physiol 94(3):1214-8. doi:10.1104/pp. 94.3.1214

Steil L, Hoffmann T, Budde I, Volker U, Bremer E (2003) Genome-wide transcriptional profiling analysis of adaptation of Bacillus subtilis to high salinity. J Bacteriol 185(21):6358-70. doi:10.1128/JB.185.21. 6358-6370.2003

Street TO, Bolen DW, Rose GD (2006) A molecular mechanism for osmolyte-induced protein stability. Proc Natl Acad Sci U S A 103(38):13997-4002. doi:10.1073/pnas.0606236103

Suarez R, Wong A, Ramirez M, Barraza A, Orozco MD, Cevallos MA, Lara M, Hernandez G, Iturriaga G (2008) Improvement of drought tolerance and grain yield in common bean by overexpressing trehalose-6-phosphate synthase in rhizobia. Mol Plant Microbe Interact 21(7):958-66. doi:10.1094/MPMI-21-7-0958

Tank N, Saraf M (2010) Salinity-resistant plant growth promoting rhizobacteria ameliorates sodium chloride stress on tomato plants. J Plant Interact 5(1):51-8. doi:10.1080/17429140903125848
Tester M, Davenport R (2003) $\mathrm{Na}^{+}$tolerance and $\mathrm{Na}^{+}$transport in higher plants. Ann Bot 91(5):503-27. doi:10.1093/aob/mcg058

Triky-Dotan S, Yermiyahu U, Katan J, Gamliel A (2005) Development of crown and root rot disease of tomato under irrigation with saline water. Phytopathol 95(12):1438-44. doi: 10.1094/PHYTO-95-1438

Tripathi AK, Nagarajan T, Verma SC, Le Rudulier D (2002) Inhibition of biosynthesis and activity of nitrogenases in Azospirillum brasilense Sp7 under salinity stress. Curr Microbiol 44(5):363-367. doi:10. 1007/s00284-001-0022-8

Tripathi NK, Annachchatre A, Patil AA (2000) Role of remote sensing in environmental impact analysis of shrimp farming. Proceedings of the Map India 2000, New Delhi, India, April 10-11, pp. 14-16

Upadhyay SK, Singh DP, Saikia R (2009) Genetic diversity of plant growth promoting rhizobacteria isolated from rhizospheric soil of wheat under saline condition. Curr Microbiol 59(5):489-96. doi:10. 1007/s00284-009-9464-1

Upadhyay SK, Singh JS, Saxena AK, Singh DP (2012) Impact of PGPR inoculation on growth and antioxidant status of wheat under saline conditions. Plant Biol 14(4):605-11. doi:10.1111/j.1438-8677.2011. 00533.x

Upadhyay SK, Singh JS, Singh DP (2011) Exopolysaccharide-producing plant growth-promoting rhizobacteria under salinity condition. Pedosphere 21(2):214-22. doi:10.1016/S1002-0160(11)60120-3

van Loon LC, Bakker PA, Pieterse CM (1998) Systemic resistance induced by rhizosphere bacteria. Annu Rev Phytopathol 36(1): 453-83. doi:10.1146/annurev.phyto.36.1.453

Vessey JK (2003) Plant growth promoting rhizobacteria as biofertilizers. Plant Soil 255(2):571-86. doi:10.1023/A:1026037216893

Volker U, Engelmann S, Maul B, Riethdorf S, Volker A, Schmid R, Mach H, Hecker M (1994) Analysis of the induction of general stress proteins of Bacillus subtilis. Microbiology 140(4):741-52. doi:10. 1099/00221287-140-4-741

Weber A, Jung K (2002) Profling early osmostress-dependant gene expression in Escherichia coli using DNA macroarrays. J Bacteriol 184(19):5502-07. doi:10.1128/JB.184.19.5502-5507.2002

Wenzel WW (2009) Rhizosphere processes and management in plantassisted bioremediation (phytoremediation) of soils. Plant Soil 321(1-2):385-408. doi:10.1007/s11104-008-9686-1

Whatmore AM, Chudek JA, Reed RH (1990) The effects of osmotic upshock on the intracellular solute pools of Bacillus subtilis. J Gen Microbiol 136(12):2527-35. doi:10.1099/00221287-136-12-2527

White PJ, Broadley MR (2001) Chloride in soils and its uptake and movement within the plant: a review. Ann Bot 88(6):967-88. doi: 10.1006/anbo.2001.1540

Xu ZH, Saffigna PG, Farquhar GD, Simpson JA, Haines RJ, Walker S et al (2000) Carbon isotope discrimination and oxygen isotope composition in clones of the F (1) hybrid between slash pine and Caribbean pine in relation to tree growth, water-use efficiency and foliar nutrient concentration. Tree Physiol 20(18):1209-17. doi:10. 1093/treephys/20.18.1209

Yao LX, Wu ZS, Zheng YY, Kaleem I, Li C (2010) Growth promotion and protection against salt stress by Pseudomonas putida Rs-198 on cotton. Eur J Soil Biol 46(1):49-54. doi:10.1016/j.ejsobi.2009.11. 002

Zahran HH (1999) Rhizobium-legume symbiosis and nitrogen fixation under severe conditions and in an arid climate. Microbiol Mol Biol Rev 63(4):968-89

Zarea MJ, Hajinia S, Karimi N, Goltapeh EM, Rejali F, Varma A (2012) Effect of Piriformospora indica and Azospirillum strains from saline or non-saline soil on mitigation of the effects of $\mathrm{NaCl}$. Soil Biol Biochem 45:139-46. doi:10.1016/j.soilbio.2011.11.006

Zhang H, Kim MS, Sun Y, Dowd SE, Shi H, Pare PW (2008) Soil bacteria confer plant salt tolerance by tissue-specific regulation of the sodium transporter HKT1. Mol Plant Microbe Interact 21(6): 737-44. doi:10.1094/MPMI-21-6-0737 